\title{
Bodies, Women and NarRatives: Imagining Corporealities and Genders
}

\author{
Begonya Enguix Grau; Ana María González Ramos
}

Universitat Oberta de Catalunya; IN3; benguix@uoc.edu; agonzalezram@uoc.edu

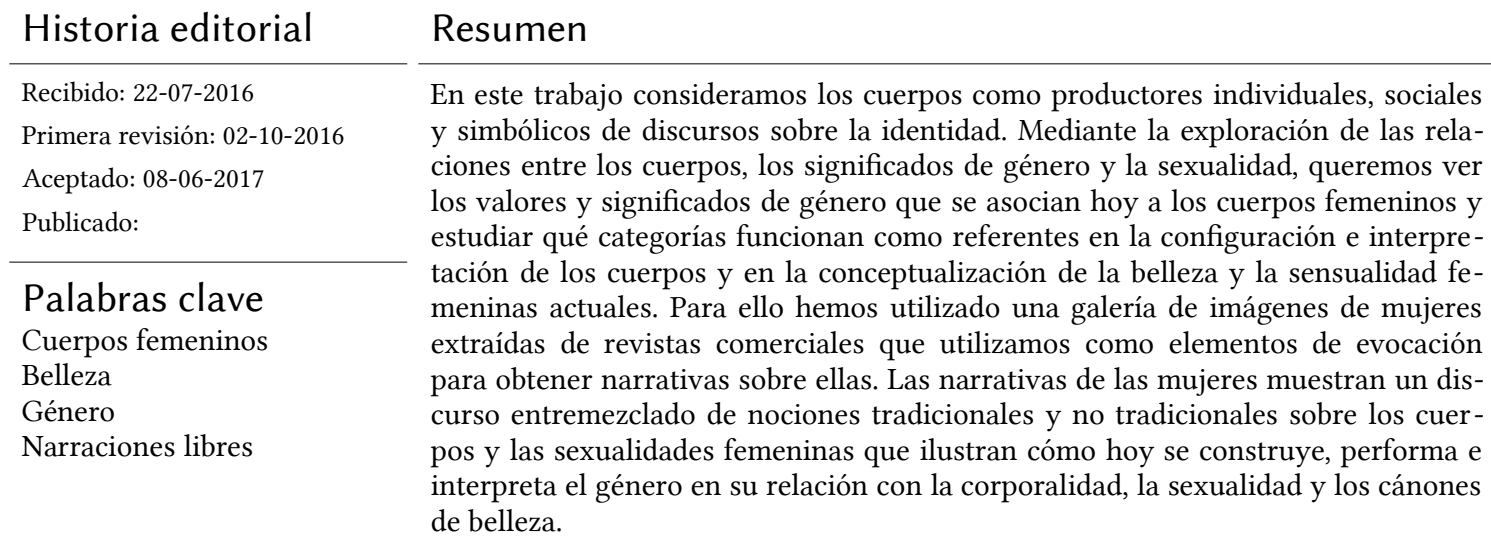

\section{Abstract}

Keywords

Female Bodies

Beauty

Gender

Free Narratives

In this work we consider that bodies are individual, social and symbolic producers of discourses about identity. Through the exploration of the connections between bodies, gender meanings and sexualities, we aim to unveil the values and meanings of gender that we associate to feminine bodies; we also aim to analyze the referential categories for the configuration and interpretation of bodies and for our understandings of women's beauty and sensuality. For that purpose, we have used a gallery of images depicting women taken from different magazines. We use that gallery to elicit narratives on the images. The narratives we have worked with show that women's discourses are now merging traditional and non-traditional ideas about feminine bodies and sexualities that illustrate the way how we build, perform and interpret gender in its relation to embodiment, sexuality, and beauty canons.

Enguix Grau, Begonya \& González Ramos, Ana María (2018). Cuerpos, mujeres y narrativas: Imaginando corporalidades y géneros. Athenea Digital, 18(2), e1956. https://doi.org/10.5565/rev/athenea.1956

\section{Introducción}

Nuestros cuerpos, la materialidad en que nos constituimos como seres humanos, no son sólo materia: con ellos y mediante ellos, producimos discursos sobre quiénes somos y como nos re-presentamos. Estos discursos son a la vez individuales, sociales y simbólicos y afectan a nuestra posición en el mundo social. En este trabajo queremos explorar cómo se relaciona el cuerpo, esa materialidad que trasciende lo material y que es a la vez, objeto y sujeto, con el género y cómo la sexualidad atraviesa esa relación y la modula, (re)produciendo modelos de belleza. Nuestro objetivo es explorar qué categorías se ponen en juego para la interpretación de cuerpos concretos -qué elementos 
se destacan en esos cuerpos-y ponerlas en relación con los imaginarios sociales sobre el género y la sexualidad. Con ello, analizaremos los códigos discursivos y las convenciones mediante las que el género se vehicula corporalmente, unos códigos que, como se desprende de las narrativas de las informantes, tienen estrechos nexos con los imaginarios sobre lo que se considera bello.

La tecnología de la sexualización (new technology of sexiness), tal como la expresa Hilary Radner (1999), afirma que los discursos de género son más importantes para la construcción de lo atractivo y lo deseable que el conocimiento sexual y la práctica sexual. Cuanto más nos acercamos a los ideales de género, mayor valor social tienen nuestros cuerpos. Por eso, las mujeres "trabajamos duramente" para conseguir que nuestros cuerpos estén modelados conforme a los cánones corporales establecidos y aceptados mayoritariamente. Las representaciones sobre el cuerpo siguen patrones basados en significados y representaciones corporales de la cultura popular, es decir, aquella producida por los medios de comunicación y de consumo masivo (Radner, 1999; Valdivia, 1997) que funcionan como modelos a seguir.

La creciente sexualización de las sociedades occidentales (Attwood, 2009; Gill, 2003; 2008; Jeffreys, 2005; Paasonen, Nikunen y Saarenmaa, 2007) y la emergencia y la visibilidad de sexualidades no hegemónicas han podido dar lugar a nuevos imaginarios sociales sobre los géneros y los cuerpos - cuerpos neutrales, musculosos, butch, transgender y/o asexuales- distintos de los tradicionalmente considerados como cuerpos atractivos y/o bellos de mujer. ¿Son estos nuevos modelos disponibles de belleza reconocidos por las mujeres? ¿Cómo son valorados e interpretados? ¿Implican cierto cambio y agencia de las mujeres sobre el modo en que entendemos la belleza? ¿Los actuales cánones de belleza permiten la construcción de nuevas posibilidades de género y/o sexualidad femenina o, por el contrario, reafirman los cánones tradicionales del pasado? ¿Se ha roto la vinculación de los ideales de belleza con el binarismo de género?

Con este trabajo queremos contribuir a los estudios sobre las relaciones entre género, sexualidad y cuerpo mediante la exploración de distintos modelos de belleza femenina y el análisis de su interpretación y valoración por parte de las mujeres. Nos interesa analizar los significados y valores que las mujeres participantes asocian a las mujeres, unos significados que pueden romper con los cánones de belleza más reconocibles y con las sexualidades más tradicionales. Consideramos que las mujeres actuales pueden generar "nuevos" marcos interpretativos relacionados con "nuevas" identidades de género y que estos marcos de referencia pueden trascender los binarismos de género y la mirada masculina y heteropatriarcal. 


\section{Cuerpos, Géneros, Sexualidades e Identidades Femeninas}

Género y cuerpo son indisociables el uno del otro, constituyéndose mutuamente como materialidades discursivas, creando un yo con un género incorporado (embodied) que se alimenta tanto de la propia subjetividad (generizada) como de las interacciones sociales y la imagen sobre los otros y de los otros sobre nosotros. Según Chris Shilling (1993), la posmodernidad trajo una creciente individualización del cuerpo, privatizando sus significados. El cuerpo como materia (body matters) y discurso, el género como discurso social encarnado en el cuerpo y sus experiencias y prácticas son depositarios de valores simbólicos y fuente de capital simbólico, no sólo por lo que el cuerpo puede hacer, sino por cómo se presenta socialmente (Bourdieu, 1997; Gill, 2003). Chris Shilling (2005 p. 2) afirma que esta presentación, nuestro yo visible (visible self), es un elemento fundamental para la constitución de nuestra subjetividad e identidad y para la constitución del estatus social, interseccionándose con el grupo étnico y la clase social (Gill, 2007). Por ello, la apariencia del cuerpo y su mayor o menor distancia de los cánones normativos de género y belleza afectan tanto a la construcción del yo como a sus relaciones sociales, y tiene una lectura en términos de poder, como afirman Kim Johnson y Sharron Lennon (1999).

Existe una clara conexión entre nuestros ideales sobre los cuerpos y las identidades de género, y el consumo (Featherstone, 1982; Giddens, 1994; Turner, 1984; Valdivia, 1997). Nuestros cuerpos se re-presentan socialmente conjuntamente con artefactos simbólicos como el vestido, el peinado, el maquillaje y otros complementos. Estos "artefactos" co-construyen una imagen corporal que puede ser leída claramente en términos de poder y estatus social. Es más, la tendencia a adoptar re-presentaciones cercanas a la normatividad hetero-hegemónica es claramente un efecto de lo que Foucault llamó "biopoder", un poder que se asienta sobre "tecnologías del yo" (Foucault, 1984; 1991). Angharad Valdivia (1997) en su estudio sobre la línea de lencería Victoria's Secret ha analizado cómo las imágenes fotográficas de los catálogos de venta de prendas de vestir representan mujeres de las clases sociales medias para favorecer la identificación de lectoras y potenciales consumidoras. En las imágenes aparecen con una pose reclinada, las piernas cruzadas insinuando cierto nivel de sensualidad y acompañadas de complementos de alta calidad que evocan cierto poder económico. Estas mujeres transmiten el valor de la opulencia y el placer de quien espera a sus invitados relajadamente, seguras de su posición social (Valdivia, 1997, p. 239).

La importancia de nuestra apariencia y desempeño corporal (performance) se relaciona tanto con la creciente sexualización de las sociedades occidentales (Attwood, 2009; Paasonen et al., 2007) como con la objetificación de los cuerpos. Aunque este 
proceso afecta a hombres y mujeres, existen diferencias de género importantes en el modo cómo los cuerpos de unos y otras se objetifican. En el caso de las mujeres, para la construcción del estatus "físico" y social de los cuerpos femeninos, continúa siendo fundamental la importancia de la mirada masculina construyéndose desde lo masculino unos cánones de género, cuerpo, belleza y atractivo que son mayoritariamente mostrados por la cultura popular y que son interiorizados y reproducidos por las mujeres. En el caso de los hombres, los cuerpos masculinos se constituyen como objetos fundamentalmente para otros hombres por la posibilidad actual de una mirada generizada y sexualizada de los hombres sobre los hombres (Schroeder y Zwick, 2004), favorecida por la visibilidad de nuevas formas de homoerotismo y sexualidad.

Puesto que los estereotipos de género son bastante estables, ciertas "apariencias" o actitudes que se asocian con la masculinidad (determinación, músculo, rudeza, fuerza, agresividad) son interpretadas como "masculinizantes" en las mujeres (Bianciotti, 2011, p. 81; Bourdieu, 1997). El cuerpo, el comportamiento, la actitud, la forma de presentarse, son leídas socialmente en clave de género y siguen parámetros generizados a partir de nuestro cuerpo (Francis, 2008, p. 215; Howson, 2005).

Los cuerpos, que reproducen o resisten los cánones normativos (estereotípicos), y las identidades cosidas a ellos, se conectan fuertemente con la sexualidad: "el género informa a la sexualidad; la sexualidad confirma el género" (Fracher y Limmel, en Rohlinger, 2002, p. 62). Nuestros cuerpos son sujeto y objeto de nociones generizadas y sexualizadas mediadas por la cultura popular (medios de comunicación y prácticas de consumo). Lo sexual es una parte fundamental de la construcción del sujeto posmoderno (cf. Bordo, 2001; Butler, 1993; Grosz, 1994; List, 2005, entre otras). La materialidad de los cuerpos que no sólo tenemos, sino que somos, se construye como base de nuestras identidades, como nexo con lo inmaterial y como elemento de valoración moral. Nuestro cuerpo, nuestra presentación ante los otros, va más allá de lo aparente: presenta y representa nuestro ser. Cuerpo, género y sexualidad son constituidos por la estructura social y nuestras expectativas sobre la belleza (y el poder).

La teoría queer aspira a romper el sistema sexo-género-sexualidad, que se considera producto (y origen) de la opresión heteropatriarcal. Gayle Rubin (1975/1996) en los años 70 y 80 ya discutía si el sistema de sexualidad debe ser analizado separadamente del de género o conjuntamente. En su texto sobre el tráfico de las mujeres (1975/1996) afirma que han de ser analizados conjuntamente, mientras que en su teoría radical de la sexualidad (1984/1989) señala que las opresiones a que dan lugar ambos sistemas son distintas y más fáciles de atajar considerando cada uno por separado. Judith Butler (1990, p. 189), por su parte, define el cuerpo como un ente "variable, una superficie cuya permeabilidad es regulada políticamente, una práctica significante en el campo 
cultural de la jerarquía de género y la heterosexualidad" . Sin embargo, la cultura popular expresada por los medios de comunicación de masas abunda en la continuidad entre cuerpo-género-sexualidad, por lo que los imaginarios sociales siguen mayoritariamente construyéndose sobre la idea de que cuerpo, género y sexualidad están íntimamente relacionados, como veremos en las narrativas en las que se basa este trabajo. Sin duda, cuerpo, género y sexualidad están interseccionados entre sí de múltiples maneras, pero a la vez se interseccionan con otras categorías sociales como la clase, la edad o el grupo étnico. Estas intersecciones conforman el juego entre lo normativo y lo desregulado, lo estático y lo dinámico, lo evocado y lo esperado, lo deseado y lo repulsivo, lo bello y lo ansiado y su incorporación a nuestros imaginarios sociales sobre los géneros y los cuerpos. En definitiva, existen cuerpos ordenados, en los que la secuencia cuerpo-género-sexualidad es coherente con el orden y los imaginarios sociales, y cuerpos desordenados en los que un elemento perturbador modifica la interpretación social sobre esa re/presentación corporal: son cuerpos que desvelan y exceden los límites normativos de la matriz heterosexual y la estructura imitativa del propio género y su contingencia (Butler, 1990, p. 187).

Los cuerpos femeninos están fuertemente sometidos a la vigilancia (Foucault, 1984) así como a la automodelación del cuerpo, para que coincida con los elementos externos de valoración del cuerpo femenino (Gill, 2007). Las mujeres necesitan autodisciplinarse y someter cada aspecto de su cuerpo y de su conducta a la regulación externa y a los ideales exigidos para conseguir la aceptación social. La imagen de las mujeres es más sensible a los juicios que hacemos sobre los cuerpos y su comportamiento social (Czarniawska, 2005), precisamente, porque la sexualidad femenina sigue estando fuertemente ligada a la maternidad y al cuidado y, por tanto, es una cuestión grupal más que meramente individual. Además, puesto que la sexualidad y los cuerpos femeninos son un instrumento de mediación y relación con los otros, en un contexto heteropatriarcal los hombres han sido tradicionalmente los espejos donde las mujeres se han mirado para lograr la aceptación social, para definir la belleza y para definir la sensualidad.

En este trabajo consideramos que, en la actualidad, existen tres elementos de transformación que han podido provocar una subversión de los valores, prácticas y costumbres relacionados con el cuerpo y la sexualidad de las mujeres. En primer lugar, puede ser un elemento de transformación la idea de que la sexualidad y las identidades de género, $\mathrm{y}$, en especial, las identidades femeninas, se hacen y deshacen (doing and undoing) (Butler, 1990; 1993) siguiendo las nuevas líneas que se desarrollan dentro del pensamiento posfeminista. En segundo lugar, las mujeres son investidas de agencia y

Las traducciones son de las autoras. Las citas de informantes que aparecen en el artículo son textuales. 
su gestión sobre el cuerpo y su disciplina sobre el cuidado del cuerpo parecen ser decisiones libres (Jeffreys, 2005) y no afectadas por la imagen proyectada para los otros. Sin embargo, los medios de comunicación y los ideales corporales mostrados por la cultura popular influyen enormemente en los modelos de belleza y la disciplina que las mujeres ejercen sobre sus cuerpos. Finalmente, la creciente visibilidad de modelos alternativos de género (agender, transgender, genderfluid) y de prácticas sexuales no heterocentristas posibilitan la emergencia de nuevos códigos discursivos corporales y modelos de belleza distintos que no están centrados en la feminidad tradicional ni en la hipersexualización femenina.

El posfeminismo es un marco referencial útil en este trabajo porque evidencia la complejidad de los discursos de género actuales, enfatiza la relación entre género y cuerpo al considerar la feminidad como una propiedad corporal, y enfatiza el individualismo, la elección y el empoderamiento de las mujeres, afirmándolas más como sujetos que como objetos (Enguix y Núñez, 2015). Rosalind Gill (2007) caracteriza el posfeminismo como una sensibilidad (de probables resonancias neoliberales) construida académicamente como respuesta a una tendencia cultural. Esta sensibilidad estaría constituida por distintos temas interrelacionados que, además de los anteriores incluyen el énfasis sobre la autorregulación, la vigilancia, la autodisciplina y el autocontrol de las mujeres, el predominio de un paradigma de renovación (makeover paradigm), el resurgimiento de las ideas sobre la "naturalidad" de las diferencias sexuales, una marcada sexualización de la cultura y el énfasis sobre el consumismo y la mercantilización de las diferencias. Además de Rosalind Gill (2007), autoras como Linda Alcoff (2002), Sarah Riley y Christina Scharff (2013), bell hooks (1996) y Angela McRobbie (2004) han analizado cómo las mujeres son sujetos autorregulados que creen estar empoderados en su agencia cuando están viviendo en marcos de opresión. McRobbie (2004, p. 261), por ejemplo, afirma que "la elección, como estilo cultural, es un modo de restricción. Se obliga al individuo a tomar las decisiones correctas". Según Rosalind Gill (2007, p. 162), las mujeres han incorporado dentro de sus discursos cierto liberalismo feminista que es considerado "de sentido común" pero, en general, los discursos feministas sobre el cuerpo y la construcción de identidades no heteronormativas son ignorados por las mujeres. Por ello, junto con la emergencia de "modelos alternativos de cuerpo-génerosexualidad" encontramos discursos sociales que enfatizan lo (hetero)normativo y condenan como "exagerados" y "extremos" otros modelos, como veremos en este trabajo. Como Gill y MacRobbie muestran, las sensibilidades posfeministas están entreveradas de argumentos feministas y antifeministas sobre las identidades, los cuerpos y las sexualidades femeninas. 


\section{Metodología}

Hacer lo implícito explícito es el reto de la mayoría de los análisis sociales. La propia identidad y los códigos estereotipados que sostienen nuestras ideas sobre la relación entre cuerpo-género-sexualidad y los cánones de belleza, con frecuencia, se construyen a partir de códigos y valores no explícitos (Armstrong y Weinberg, 2006) que se ponen en funcionamiento en lo que Erving Goffman (1987) llamó "el arte de manejar las impresiones". Cuando nos encontramos con una persona, sabemos situarla en una escala de feminidad/masculinidad y valorar su atractivo en función de los parámetros sociales, pero en cambio, es complejo objetivar los elementos que utilizamos para interpretar su re/presentación. Por ello, en este trabajo optamos por utilizar la técnica de evocación (elicitation) (Collier, 2001) utilizando imágenes femeninas como estímulo para la redacción de narrativas libres sobre la relación entre cuerpo y género en base a la imagen representada. El uso de imágenes es un recurso útil para el análisis social (Rohlinger, 2002, p. 62) y para el análisis de la relación entre género y representación visual (Goffman, 1979).

En este trabajo, partimos de la utilización de fotografías mayoritariamente publicitarias, escogiendo imágenes que fueran referentes de los valores dominantes en la cultura popular (Rohlinger, 2002, p. 63) y otras que fueran evocadoras de otras identidades de género. Consideramos que las imágenes son "artefactos sociopolíticos" que producen significados y que trascienden los mensajes pretendidos por las marcas, las agencias o los fotógrafos (Shroeder y Zwick, 2004 p. 24). Las imágenes publicitarias producen valores dominantes (Callen, 1998, p. 606) que representan el mundo interior (yo identitario) y exterior (Armstrong y Weinberg, 2006; Czarniawska, 2005; Schroeder y Zwick, 2004, p. 45). Estos valores expresados en los medios de comunicación están atravesados por las relaciones de género (Nixon, 2003; O’Barr, 2008; Ragusa, 2003; Saucier y Caron, 2008, entre otros).

En trabajos previos sobre los cuerpos masculinos (Enguix, 2012; 2013; 2014), las imágenes publicitarias demostraron ser un buen instrumento de análisis para estudiar la relación entre sexualidad, género y cuerpo, y poner a prueba nuestra competencia cultural y los valores simbólicos que asociamos a las imágenes (Armstrong y Weinberg, 2006). Las imágenes publicitarias ofrecen la posibilidad de analizar los discursos dominantes (Rohlinger, 2002, p. 63) porque en su aspiración por alcanzar segmentos variados de público ofrecen distintos referentes de género, cuerpo y sexualidad. Para confeccionar la galería fotográfica en la que se basa este trabajo, se consultaron numerosas revistas dirigidas a mujeres (de tendencias, literarias, de moda, de información, etc., ver anexo) y se preseleccionaron 50 imágenes. Buscamos captar la "negociación cultural" de significados a la que alude Christine Gledhill (en Van Zoonen, 1994, p. 8) 
que está basada en la co-construcción (medios-audiencias) de los discursos mediáticos y en la pulsión entre la codificación y la decodificación (Hall, 1980). Con estas 50 imágenes como punto de partida, las autoras mantuvimos varias reuniones para elaborar una clasificación que nos permitiera diversificar los referentes de belleza y sexualidad y no reproducir modelos estereotípicos de mujeres. Aunque todas las tipologías se sesgan por los propios prejuicios que las construyen, resultaba imprescindible elaborar un listado de características sobre los modelos de género y belleza que guiara nuestra selección y sirviera para provocar narrativas y evocaciones por parte de las mujeres participantes en este estudio. Por ello, procuramos incluir diversos modelos de feminidad que incitaran la producción de narrativas de las que emergieran significados en las miradas contrapuestas del otro.

La galería fotográfica definitiva está formada por 16 imágenes femeninas que enviamos a las participantes del estudio. Puesto que nuestro objetivo es ver cómo se relacionan cuerpo-género y sexualidad y también saber si existe una ruptura en los cánones heteronormativos que han configurado tradicionalmente los cánones de belleza femenina, la galería se construyó incluyendo imágenes que evocaban performances masculinizantes, agender, transgender $y$ andróginas.

Este proceso de selección aportó un primer dato fundamental, pues comprobamos que los modelos de feminidad se alinean con los gustos asociados a los hombres y que, por tanto, no existe una amplia diversidad de modelos de belleza femenina disponibles en la prensa gráfica. Aunque las modelos tengan características específicas (vitíligo en la piel o una cara dañada por el ácido) los modelajes de su imagen son idénticos a los de las modelos más estándares. A pesar de esta uniformidad subyacente, ampliando la muestra de revistas e incluyendo ediciones internacionales, pudimos incorporar varios modelos diferentes de belleza femenina (desde las hipersexualizadas a las musculosas, las andróginas y agender).

Nuestra tipología inicial se basó en la consideración de que el género es un continuo entre lo masculino y lo femenino (Enguix, 1996; 2010) y las imágenes se escogieron en función de su representatividad de diferentes modelos de género, desde los modelos de mayor feminidad a otros agender o marcados por características asociadas a la masculinidad (musculación, androginia y transexualidad). En el primer grupo que establecimos, se incluyeron representaciones femeninas hipersexualizadas (con rasgos sexuales destacados, como pechos, labios, caderas, etc.) y mujeres con diversas características (mujeres-niña, adolescentes, e incluso actrices y políticas como Catherine Deneuve y Christine Lagarde que representaban la fama y el poder). Con la intención de interrogar el binarismo de género (Butler, 1990; Rubin, 1975/ 1996), en el segundo grupo se incluyeron dos imágenes procedentes de la campaña de los grandes almacenes 
neoyorquinos Barneys con modelos transgender (muchos de ellos inter o transexuales), que transmiten una imagen de género no marcada o indefinida (agender/ungender). En el tercer grupo se incluyeron imágenes de mujeres más masculinizadas según los cánones tradicionales y que también considerábamos alternativas a los ideales tradicionales de feminidad. También tuvimos en cuenta para la selección la edad, el grupo étnico, la sofisticación del contexto y otros elementos, como la pose o la clase, que pudieran evocar ideas y comentarios (Valdivia, 1997). Con estas imágenes tratábamos de superar el binarismo heteronormativo y analizar cómo se construyen narrativas sobre modelos de belleza no estandarizados. Las imágenes se dispusieron de manera aleatoria y no agrupadas por categorías, de tal manera que la categorización expuesta sólo representaba una categoría analítica para las investigadoras, que podría emerger o no de los discursos de las mujeres participantes en el estudio.

La galería de imágenes fue enviada a través de correo electrónico ${ }^{2}$ con una breve explicación de los objetivos del trabajo y una invitación a comentar cada una de las imágenes. No se daban más directrices que las del texto enviado por mail para provocar en las informantes narraciones sobre las imágenes que fueran libres - no pautadas ni estructuradas de antemano- y poder así analizar cómo a partir de una imagen se evocan significados de género y conglomerados de otros significados que se asocian a los géneros. Nuestra intención era conseguir al menos 30 informantes que obedecieran a distintas características socio-demográficas en razón a su ocupación, edad y orientación sexual. Por tanto, se eligió un grupo heterogéneo de mujeres que podían reconocerse o reconocer disimilitudes con las mujeres representadas en la galería fotográfica. La estrategia de bola de nieve que se empleó para la recogida de respuestas tuvo escasa efectividad y sólo se consiguieron 23 respuestas. Las mujeres que respondieron a nuestra petición oscilan entre los 28 y los 59 años, son de nacionalidad española y tienen mayoritariamente estudios universitarios (trece personas). Dieciséis se identifican como heterosexuales, dos mujeres se identifican como bisexuales, tres como lesbianas y dos dejaron en blanco este apartado. En el mensaje de envío, se les pedía que enviaran las respuestas a la primera autora de este trabajo, empleando un seudónimo (que utilizamos aquí para exponer los resultados) y que respondieran a algunas preguntas con propósitos exclusivamente analíticos (edad, profesión y orientación sexual). El pe-

\footnotetext{
${ }^{2}$ Este es el texto enviado por mail para acompañar la galería de imágenes: "Hola, somos un equipo de investigación de la UOC que trabaja en las representaciones sobre las mujeres. Nos gustaría saber qué opinas sobre estas mujeres, qué representan para ti y qué imagen piensas tú que ellas tratan de transmitir.

Os adjuntamos una selección de fotos que muestran distintos modelos femeninos. Os pedimos que comentéis cada foto, lo que os parece, lo que os sugiere, lo que os evoca, utilizando tanto espacio como necesitéis.

Os agradeceríamos que hicierais circular esta galería fotográfica entre personas que conozcáis, con el fin de conseguir tantas respuestas como sea posible”.
} 
ríodo de recogida tuvo lugar fundamentalmente entre septiembre y diciembre de 2014 y se repitieron los reclamos de respuesta hasta en tres ocasiones.

Las respuestas de todas las informantes a una misma galería de imágenes nos permiten analizar hasta qué punto están de acuerdo con los modelos de belleza y respecto a los cánones de masculinidad y feminidad; también permiten reconocer la presencia/ausencia de estos códigos en los cuerpos re-presentados. Las respuestas recibidas fueron analizadas mediante el análisis de contenido atendiendo tanto a los temas enunciados por las informantes para cada imagen (contexto, postura, elementos destacados, adjetivos utilizados etc.) como a las categorías de género y cuerpo que tomamos como punto de partida y que, como explicaremos, fueron modificadas para ajustarse a las narrativas obtenidas. Las respuestas recibidas fueron en general cortas y ricas en adjetivos. Con frecuencia, las mujeres del estudio se ponían en relación con la imagen representada, bien identificándose o bien distanciándose. Son precisamente las imágenes que más distancia provocan las que dieron lugar a narraciones más largas.

\section{Mujeres haciendo y deshaciendo sus identidades de género}

En este apartado expondremos las narrativas de las mujeres desde la clasificación surgida de sus comentarios y no desde la tipología prediseñada por las autoras. Si bien la tipología inicial de las autoras se conformó en base a los grados de feminidad y masculinidad asociados a las imágenes por las autoras, de las narrativas de las informantes se deriva una clasificación distinta que es la que utilizamos para mostrar los resultados. De las narrativas de las mujeres participantes en esta investigación emerge una clasificación que también consta de tres grupos: mujeres erotizadas, mujeres no erotizadas ni relacionadas con la sexualidad (que hemos denominado "mujeres tranquilas" utilizando el término apuntado en numerosas narrativas para referirse a ellas), y mujeres que por diversas razones, como veremos, se relacionan simbólicamente con referentes masculinos.

\section{Mujeres hipersexualizadas, construidas para erotizar}

A través del análisis de las representaciones fotográficas, las mujeres van haciendo y deshaciendo su propio género y el de las mujeres representadas mediante la aplicación de ciertos estereotipos, para reafirmarlos o cuestionarlos (Butler, 2004). A partir de los discursos de las mujeres, podemos afirmar que los modelos tradicionales sobre las mujeres y la belleza, ligados a la sexualización, persisten, aunque también se discuten. Muchos de los comentarios dedicados a las modelos hipersexualizadas rechazan la co- 
sificación de las mujeres por ser dependientes de la mirada erótica masculina. Se afirma de ellas que son mujeres "para alguien", "para revistas de hombres", "putones de revista de tíos antes de quitarse la ropa!!” (Xx, narrativa, 30 septiembre 2014), que "enseñan el cuerpo para" (Marta, narrativa, 19 septiembre 2014) y que muestran una "imagen muy estereotipada sobre la mujer como objeto de deseo" (Blabla, narrativa, 30 septiembre 2014).

Las informantes rechazan este tipo de imágenes de mujeres que identificaron con tres imágenes de la galería fotográfica, entre ellas la correspondiente a la figura 1 , porque no inspiran nada y sólo evocan

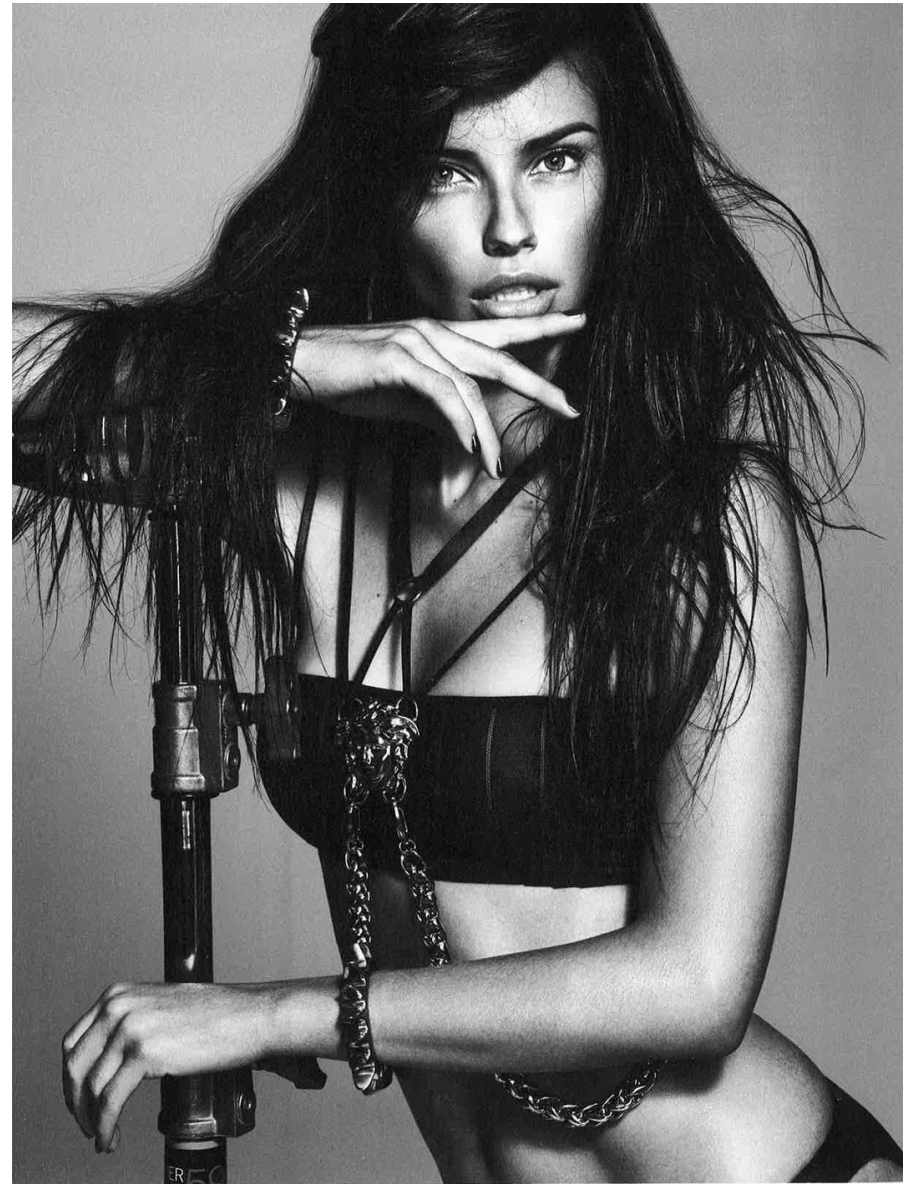

Figura 1. Fuente: Harper's Bazaar España, núm. 44. febrero 2014 sexo para la provocación de la mirada masculina. Son las imágenes peor valoradas, independientemente de la orientación sexual de las informantes. Este rechazo no parte de discursos feministas o de transformación de las experiencias femeninas, sino que se articula a partir de valores de un feminismo liberal que enfatiza el individualismo, la autorregulación y el autocontrol de las mujeres en su tránsito de objeto a sujeto (Gill, 2003; 2007). La única excepción es Towanda, quien en su narrativa afirma (9 octubre 2014): "no puedo con ellas, en una sola foto echan abajo todas las batallas que mantenemos el resto de mujeres por nuestros derechos”. Estas modelos también sugieren comentarios más condescendientes: Lutecia (narrativa, 2 junio 2015), Arca (narrativa, 9 octubre 2014) y Marta (narrativa, 19 septiembre 2014) las consideran femeninas y sensuales; para Blabla (narrativa, 30 septiembre 2014) representan la autoestima y el poder y para Otra Raya más al Tigre son "muy sexy, gusta mirarla" (narrativa, 9 octubre 2014). Esta diversidad de opiniones refleja contradicciones posfeministas y la reapropiación que las mujeres hacen de la mirada heteronormativa. 
De estas mujeres, entendidas como reclamo erótico, se destacan partes corporales como los pechos, la mirada sensual, la escasez de ropa, la exuberancia de las formas corporales y la boca semiabierta. Todas las informantes, independientemente de su orientación sexual, consideran a las mujeres incluidas bajo esta categoría como "guarronas" (Marichuli, narrativa, 9 octubre 2014), "provocativas" (Arca, narrativa, 9 octubre 2014) o "sexies". Piensan de ellas que son mujeres-objeto para el deseo masculino $\mathrm{y}$, por tanto, las rechazan, aunque también las normalizan, diciendo de ellas que son "la mujer típica". Como la evocación que hacen de estas representaciones femeninas es que sólo están pensadas para el placer masculino, no provocan auto-identificación entre las informantes, sino que las consideran ajenas a ellas mismas.

\section{Mujeres no erotizadas: la construcción de la sencillez en las mujeres "tranquilas"}

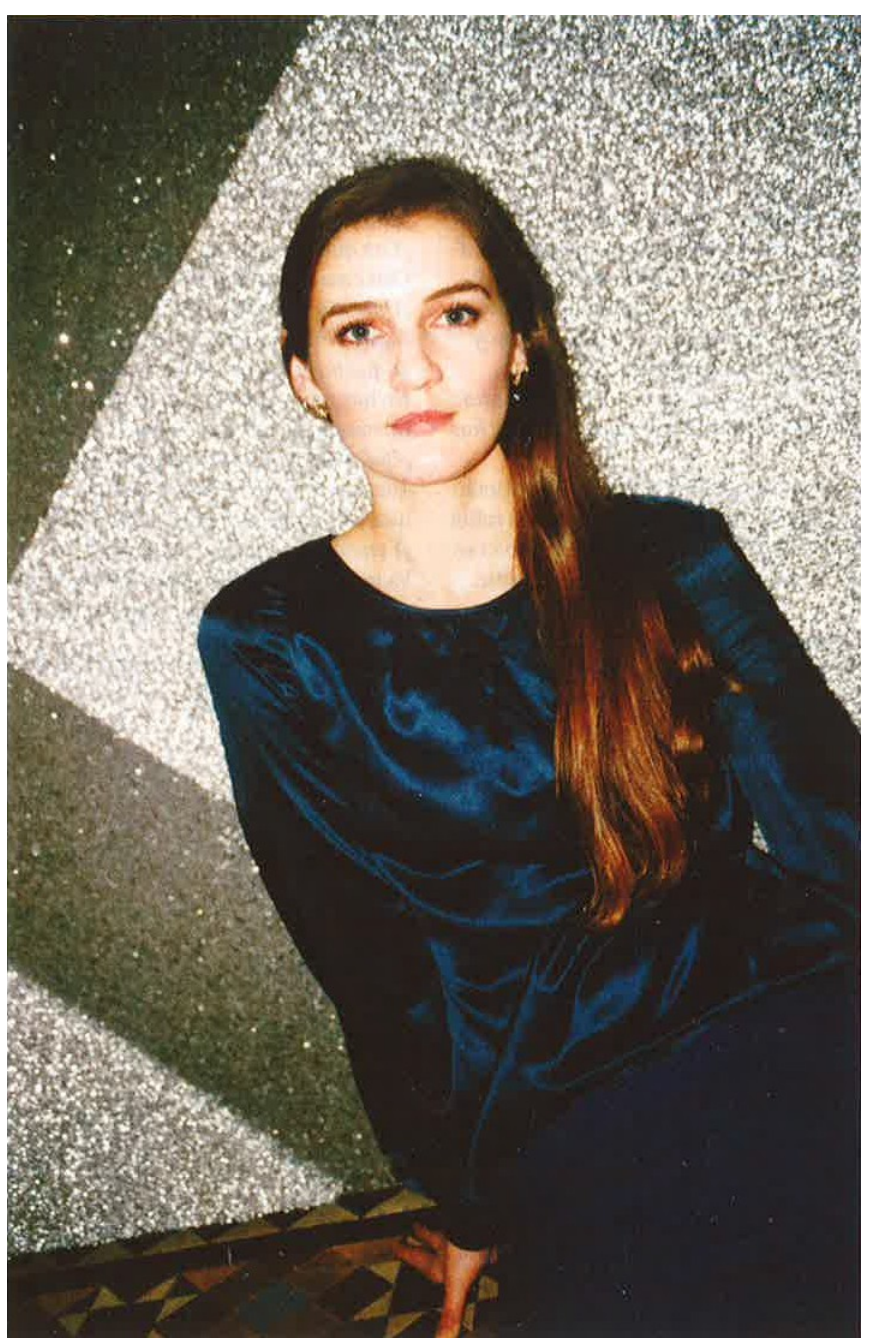

Figura 2. Fuente: Vanidad núm. 202, febrero 2014
La segunda categoría de mujeres que emerge de las narrativas podría clasificarse como "neutral" o referida a las mujeres que no transmiten erotismo ni sexualidad. Las informantes asignan esta categoría a seis imágenes de la galería. En este caso, las narrativas se centran más en los sentimientos e impresiones "transmitidos” por estas imágenes (la sencillez, la naturalidad, la normalidad, la feminidad y la tranquilidad) que en sus cuerpos. Son las mujeres mejor valoradas porque son consideradas mujeres autónomas y con confianza en sí mismas.

Pero los sentimientos agradables se acompañan de otros adjetivos menos positivos: la imagen reproducida en la figura 2 evoca una chica "clásica, gris, sin chispa" (Towanda, narrativa, 
9 octubre 2014) o una "chica del montón" (Marta, narrativa, 19 septiembre 2014). La "normalidad" se construye a partir del término medio (ni hipersexualizada ni marcada por rasgos físicos masculinos o transgender):

Una imagen cuidada pero discreta... maquillaje correcto (ni poco ni mucho). Su pelo cuidado en una melena larga y bonita, pero sin aspecto de haber pasado horas en la peluquería. Su vestuario es bonito, pero no realza en extremo su cuerpo, no marca ni su cadera ni sus senos. Su pose es natural, para sí es una persona que no necesita llamar la atención sobre ella, se siente bien y no necesita llamar la atención sobre su persona. Por desgracia esta imagen no vendería en las revistas de moda, no llama en extremo la atención sobre nada de ella (Blabla, narrativa, 30 septiembre 2014).

La juventud también aparece vinculada por las informantes con una idea de "normalidad" y estándar de belleza y se muestra como un elemento deseable. Las figuras 2 y 3 son las más representativas de este posicionamiento. La juventud impregna algunos relatos de nostalgia: "Belleza juvenil que se me ha pasado... inocencia urbana" (Marta, narrativa, 19 septiembre 2014); "la chica que era yo, por ejemplo. Mirada intensa y limpia, con carácter a pesar de su juventud. Es dueña del mundo sin serlo de nada. Lo tiene todo porque todo lo espera y sin ambicionar nada. La que más me gusta hasta ahora" (Patty, narrativa, 21 octubre 2014). También evocan positividad: "belleza simple y natural, alegría, veo lo nuevo y fresco de la vida" (Mariví, narrativa, 3 octubre 2014), "representa juventud, frescura, inocencia, dulzura, sencillez" (Olfarnau, narrativa, 21 octubre 2014); "juventud, fragilidad, honestidad, inocencia" (Noah Norel, narrativa, 22 octubre 2014).

Los modelos estándares de belleza femenina están íntimamente ligados a esta etapa vital: "timidez, juventud, confianza" (Ilota, narrativa, 21 octubre 2014), "inocente y segura" (Tirita narrativa, 21 octubre 2014), "natural, normal... belleza de la juventud... frescura de la adolescencia" (Marilu, narrativa, 9 marzo 2015), "belleza simple y natural, alegría, veo lo nuevo y

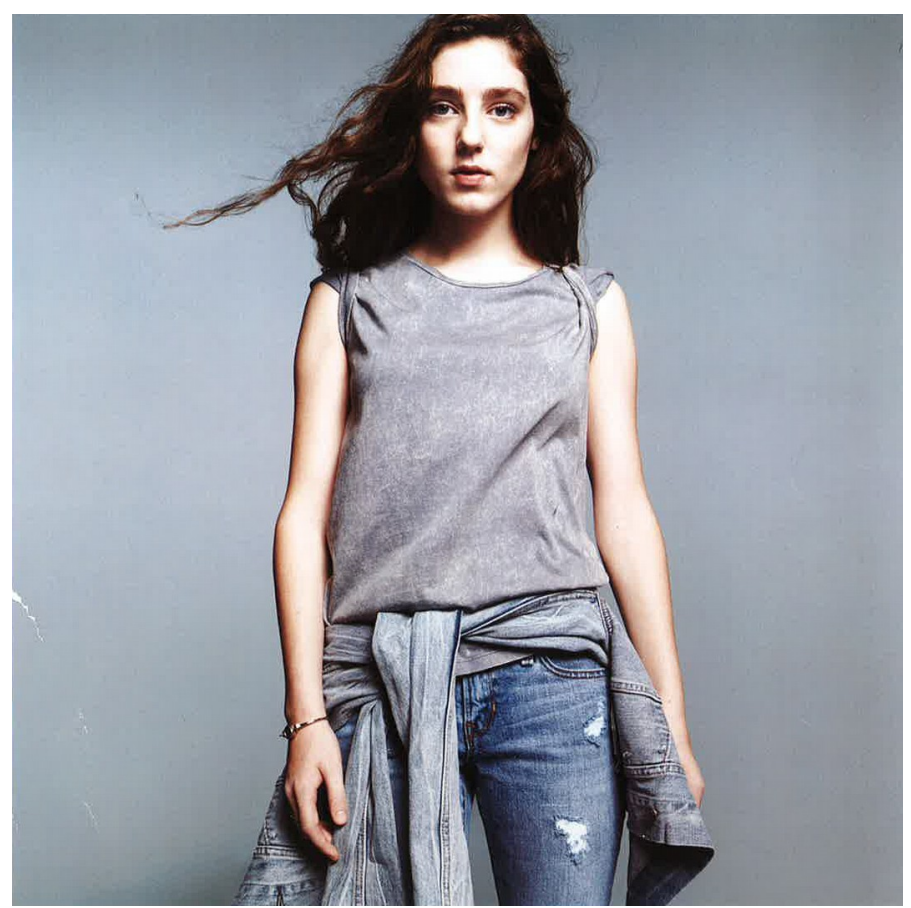

Figura 3. Fuente: Vogue USA, marzo 2014 
fresco de la vida" (Mariví, narrativa, 3 octubre 2014), son algunos de los términos que aparecen. Así, la juventud queda asociada a características positivas en sintonía con los imaginarios sociales.

El contexto de las imágenes crea una historia que propicia un imaginario sobre la belleza y el poder que representan las imágenes (Valdivia, 1997). Las informantes utilizan, incluso cuando no los hay, referencias a contextos comerciales o mediáticos para explicarse ("son una imagen del Corte Inglés", "imagen de la década de los 90", "pinups", “Thelma y Louise", "anuncios de Gafas Don Algodón”). Este discurso recurrente que elabora "historias" respecto a las imágenes -incluso las más alternativas de la campaña transgender de Barneys (Nueva York) - muestra la persistencia de la influencia de los modelos estéticos transmitidos por la cultura popular y los medios de comunicación.

La figura 4 muestra una mujer en un salón (se considera el salón de su casa) y suscita evocaciones complejas. Se la interpreta como una "ama de casa burguesa" (Otra Raya más al Tigre, narrativa, 9 octubre 2014), mantenida por su "marido rico" (Mari-

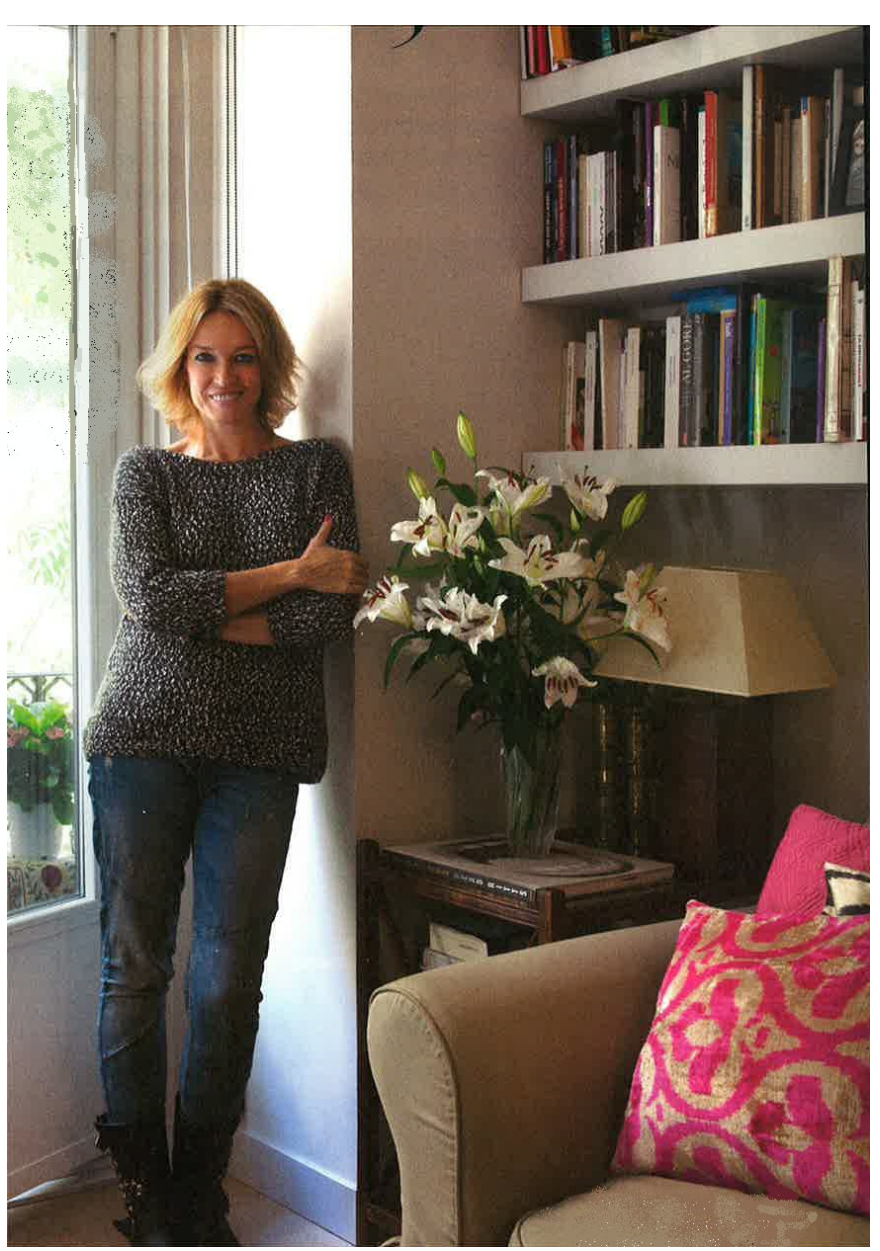

Figura 4. Fuente: In Style núm. 114, febrero 2014 chuli, narrativa 9 octubre 2014). Las informantes también evocan el ambiente, más que la propia figura femenina, interpretando que es una "invitación a la lectura, relajación, buen ambiente, orden, equilibrio, armonía, tranquilidad" (Ilota, narrativa, 21 octubre 2014): Lenademar (narrativa, 22 octubre 2014) piensa que es "una escritora famosa... Me encantan tanto los libros como las flores. Me gusta que sonría y que mire a la cámara. Parece segura de sí misma, aunque se protege de algo, al menos la colocación de sus brazos me da esta impresión. Tal vez tiene pudor de enseñar su casa”. Esta imagen también evoca la profesión y estatus de la mujer representada: "[es una] mujer normal. Vestida nor- 
mal. Peinada normal. Pose normal. Parece invitarnos a pasar a su casa... que por cierto parece una casa normal" (Xx, narrativa, 30 septiembre 2014). Finalmente, el hogar se identifica con el orden y la felicidad, con la "normalidad".

En este grupo de imágenes se incluye la imagen de Christine Lagarde, directora del FMI, y de la actriz Catherine Deneuve en una campaña publicitaria para Louis Vuitton. Ambas representan la madurez para la mayoría de las informantes. Respecto a Christine Lagarde se dice que es la representación del poder, al tiempo que se rechaza que el poder sea un elemento deseable. Por ejemplo, Towanda escribe en mayúsculas en su narrativa (9 octubre 2014): "la que es fea por dentro, es fea por fuera". La edad madura es rechazada como referente femenino porque el "pelo canoso, que aunque dicen que a los hombres les hace parecer interesantes creo que a las mujeres nos hace parecer mayores" (Blabla, narrativa, 30 septiembre 2014), aunque Patty (narrativa, 21 de octubre 2014) dice: "Su pelo blanco transmite aires de integridad y honestidad. Dinamismo y resolución. Está en el poder, eso seguro”. Esta imagen suscita también sentimientos positivos: "ejecutiva/directiva. Se ha ganado a pulso cada logro profesional conseguido, se mueve en un mundo predominantemente masculino y quiere ir correcta pero mantener su feminidad, segura de sí misma, carácter fuerte, madura, atractiva" (Tirita, narrativa, 21 octubre 2014) y sentimientos negativos: "Me inspira hipocresía" (Lenademar, narrativa, 22 octubre 2014). Curiosamente, la mayor parte de las informantes no reconocen a Christine Lagarde, pero la asocian a una ejecutiva con poder por su pose, estilo de vestir y pelo canoso. A su vez, la profesionalidad y el poder se relacionan con la no-maternidad: “(...) no parece ser madre y si lo es, tendrá sólo un varón” (Marilu, narrativa, 9 marzo 2015).

Catherine Deneuve recibe numerosas críticas por sus operaciones de cirugía y por parecer demasiado arreglada: "Qué mal sienta no saber llevar tu propia edad :-D" (Maléfica, narrativa, 9 octubre 2014). Blabla dice de ella en su narrativa (30 septiembre 2014): "no creo que una no pueda ser hermosa con la edad, de hecho, muchas mujeres o hombres ganan con ella. Lo que no podemos pretender es tener el mismo estilo de cuando éramos jóvenes". A Mariví no le atrae "como mujer a imitar" (narrativa, 3 octubre 2014) y Marilu cree que "parece de la década del 90 por el maquillaje y los flecos de la ropa. De ella puedo imaginar que es una madre de familia, amante de las telenovelas y los dramas. Emocional y dominante. Mostrando una cartera de la nueva colección de vaya a saber qué firma y haciendo su mejor cara de diva" (narrativa, 9 marzo 2015). Marichuli, sin embargo, dice en su narrativa (9 octubre 2014): "ésta sí que sabe envejecer...siempre es elegante y parece siempre saber estar. Pero tiene ese toque frío... es distante", quizá porque, como afirma Towanda, "estar siempre perfecta es agotador" (narrativa, 9 octubre 2014). 


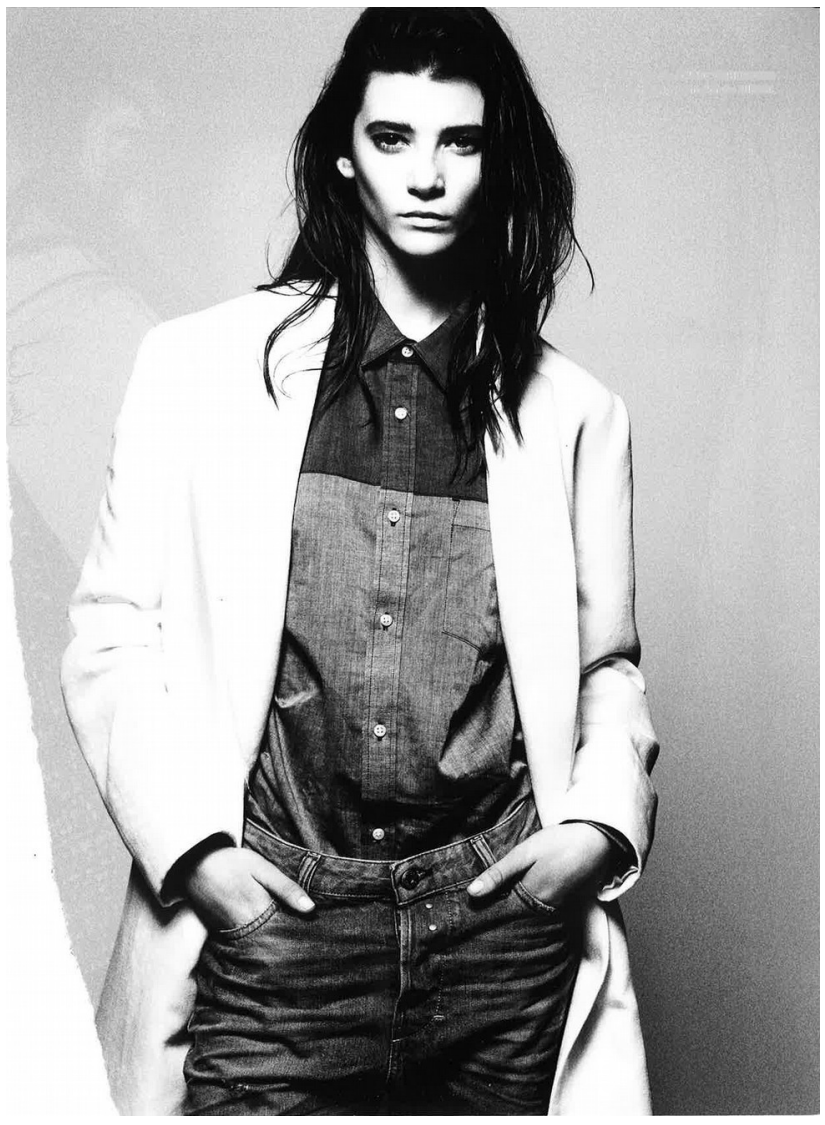

Figura 5. Fuente: Vanidad núm. 202, febrero 2014

Las narrativas sobre la imagen reproducida en la figura 5 posicionan este modelo de mujer como la representación de una feminidad intermedia, como un canon de transición entre los distintos modelos femeninos: "Masculina (por ropa) pero femenina al mismo tiempo (pelo largo, segura de sí misma, desafiante, con las cosas claras. [...] Esta chica no necesita protegerse y se muestra sin barreras" (Tirita, narrativa, 21 octubre 2014, ).

Blabla (narrativa, 30 septiembre 2014) afirma:

$$
\begin{aligned}
& \text { La postura en la que } \\
& \text { posa es totalmente } \\
& \text { masculina, la ropa } \\
& \text { también. Hasta en la } \\
& \text { camisa que lleva } \\
& \text { abrochada totalmente }
\end{aligned}
$$
para no insinuar ni ligeramente el comienzo de los senos. Ni siquiera lleva las uñas pintadas. Para mi quiere trasmitir una mujer segura de sí misma y que pasa de las modas. Pero a pesar de llevar ropa con un aire masculino, no me parece una mujer homosexual. Tiene una cara femenina y transmite un aire de cierta fragilidad a pesar de su imagen.

Muchas informantes califican esta imagen como "andrógina" (Arca, narrativa, 9 octubre 2014), con "dosis de masculinidad" (Maléfica, narrativa, 9 octubre 2014) y "carente de estereotipos" (Towanda, narrativa, 9 octubre 2014). De ella se enfatiza la mirada, el pelo, los pómulos marcados y la ropa, pero también la ausencia de atributos femeninos destacables (su ausencia de pechos, según Blabla; narrativa, 30 septiembre 2014). Recibe la aprobación de unas ("No me importaría que estuviese en mi círculo de amistades", Xx, narrativa, 30 septiembre 2014), y el rechazo de otras ("No me identifico tampoco con esta imagen, creo que la mujer tiene muchas facetas y esta imagen es muy marcada de un prototipo de mujer”, Blabla, narrativa, 30 septiembre 2014). Su aire desenfadado y su pose transmiten seguridad, independencia y autoconfianza. 
En este grupo, las mujeres mejor valoradas son aquellas que, por un motivo $\mathrm{u}$ otro, representan autonomía y confianza en sí mismas; estas características se relacionan en las narrativas con rasgos masculinos de carácter. Por ejemplo, sobre la figura 5, NormaRey dice: "Me inspira masculinidad, agresividad en la mirada y gesto facial. Fuera de un contexto de 'pose para la foto', pensaría que es una tía que sabe lo que quiere" (narrativa, 9 diciembre 2014).

Esta imagen, claramente asociada a lo masculino por su postura, estilo de ropa, falta de senos prominentes y falta de maquillaje, lleva a las informantes a cuestionarse su orientación sexual, algo que no había sucedido respecto a las imágenes anteriores. La imagen reproducida en la figura 5 se asocia a una multiplicidad de orientaciones sexuales posibles entre las que destacan "masculina-homosexual" (Blabla, narrativa, 30 septiembre 2014), "asexual" (Mes, narrativa, 9 octubre 2014), "bisexual" (Mjou, narrativa, 9 octubre 2014) y "andrógina” (Otra Raya más al Tigre, narrativa, 9 octubre 2014).

\section{Mujeres no estándar, musculadas, agender y transgender}

La asociación entre cuerpo, género y orientación sexual emerge con fuerza en las narrativas sobre este grupo de imágenes, que incluyen cuerpos femeninos musculosos y andróginos. Resulta interesante destacar que ninguna informante reconoció a los/as modelos transgender de la campaña de Barneys. La categoría "mujer” y el binarismo impregnan con fuerza los significantes de los cuerpos representados y rara vez se cuestiona que las figuras femeninas representadas puedan no ser mujeres biológicas. Las dudas sobre el sexo de la modelo sólo aparecen respecto a la imagen reproducida en la figura 6 que representa a una mujer muy musculada.

Esta imagen muestra el torso de una mujer musculada, con el cabello muy rasurado, la cara y las uñas pintadas y con pendientes, mostrando sus bíceps y pectorales al tapar los pechos

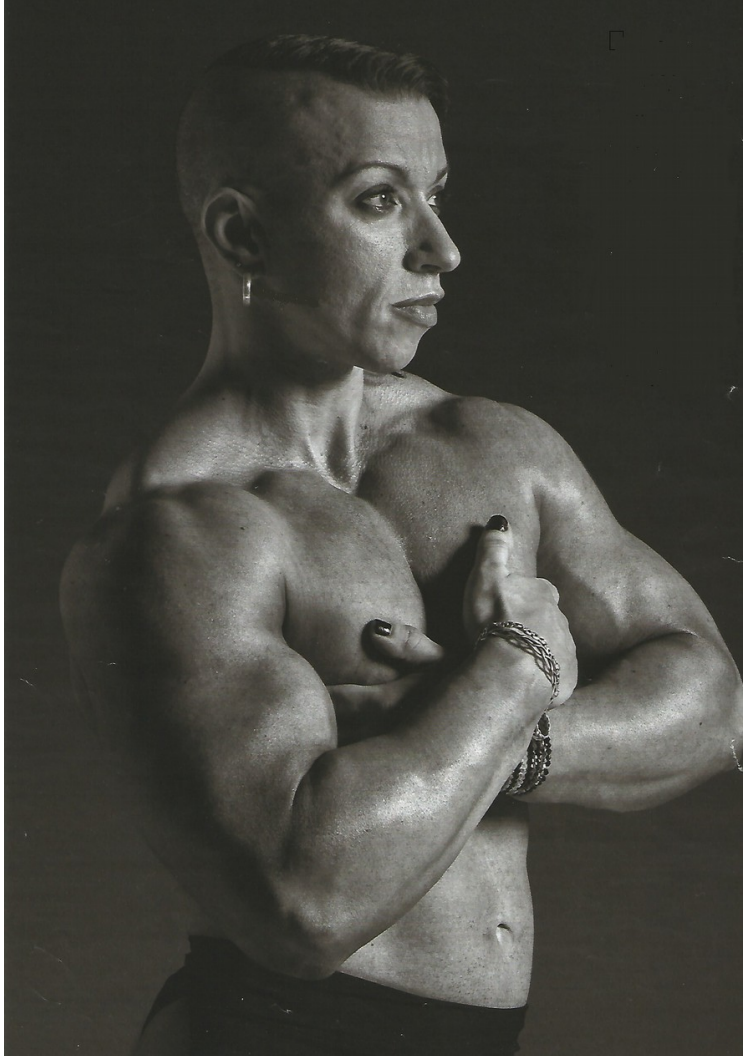

Figura 6. Fuente: S Moda, núm. 114, 24 Nov. 2013 
desnudos. Las narrativas sobre esta imagen son las más extensas, aunque en ellas las informantes no hablan tanto del cuerpo como de los sentimientos que les inspira, tales como la rebeldía, la fuerza y la seguridad. Esta es la imagen donde quedan de relieve más claramente la fluidez y las contradicciones de las identidades corporales femeninas. De esta mujer se dice que combina cánones masculinos y femeninos, que es "un cuerpo de hombre con cara de mujer" (Alicia en el país de las maravillas, narrativa, 30 septiembre 2014). Ofrece la oportunidad de discutir los cánones de belleza corporales y las diferencias de género, confirmando que los cánones de belleza y el atractivo se establecen de una manera relacional entre la persona y las emociones que esa persona suscita en su entorno (Czarniawska, 2005; Galak, 2011; Schroeder y Zwick, 2004). El atractivo y la belleza nos ponen en relación con los otros: "Con estos brazos y este pelo pocos hombres se le acercarían con intención de seducirla... y pocas mujeres también" (Xx, narrativa, 30 septiembre 2014).

En las narrativas, esta imagen provoca la emergencia de dos cuestiones: en primer lugar, la interrogación sobre el sexo de la persona representada, ya que Arca (narrativa, 9 octubre 2014) cree "que es un hombre con maquillaje" y Tirita (narrativa, 21 octubre 2014) que es "un chico maquillado más que una mujer andrógina. Todo y que si tuviera más pecho y menos músculo podría ser un butch dentro del mundo lésbico. Pensativo, emocionado, protegiéndose con los brazos cruzados, no sé si de no tener mamas o por cosas del carácter". Según Marilu (narrativa, 9 marzo 2015), "en esta imagen veo un cuerpo de varón bien fuerte con cara de mujer y joyas femeninas. Lo primero que pienso es que se trata de un hombre homosexual, también podría ser transformista, bailarín y actor".

De esta interrogación por su sexo se deriva la interrogación sobre su sexualidad: puede ser un hombre homosexual, puede ser una lesbiana butch, puede ser un transexual. Una informante lesbiana, Lenademar (narrativa, 22 octubre 2014), se posiciona claramente ante la imagen, afirmando que le encanta. La interrogación, el desconcierto y el rechazo que provoca esta imagen están relacionados con la "trangresión, provocación, rebeldía frente a las normas establecidas por los tópicos” (Arca, narrativa, 9 octubre 2014), tal y como ha defendido Rosalind Gill (2007). Marichuli en su narrativa (9 octubre 2014) admira "el valor de ellas a perder esa 'feminidad' mal entendida socialmente, renunciar al aspecto femenino obligado". Esta imagen "busca el contraste entre masculinidad - la fuerza en el corte de pelo, en los músculos, en la seriedad del rostro - y feminidad con el pendiente, pulsera, uñas pintadas y cara maquillada" (Ana, narrativa, 21 octubre 2014). A la vez, la imagen es considerada "muy bella ya que se puede apreciar en una misma persona la belleza de los dos sexos, por un lado, la fuerza y firmeza de lo masculino y, por otro, el brillo, la delicadeza y hasta por su mirada, un to- 
que de sensibilidad femenina" (Marilu, narrativa, 9 marzo 2015). Por otra parte, esta figura musculada también transmite sufrimiento, lucha, fortaleza, lo que aparece ligado "inevitablemente" en las narrativas al aspecto varonil de la mujer fotografiada y a la transgresión de las normas aceptadas mayoritariamente.

La galería incluye también la imagen de otra mujer musculada en traje ceñido y postura tensionada, que muchas informantes asociaron con la postura de una bailarina flamenca. Es una culturista como la mujer representada en la figura 6, pero su cabello es largo y está recogido en un moño y lleva puesto un traje ajustado. Estos elementos son definitivos para cambiar la dirección del discurso que, aunque también transitado por la indefinición, no interroga el sexo de la representada. Cinco mujeres hablan del cuerpo y el vestido de esta mujer como compensación entre lo masculino (cuerpo musculado o "exceso de músculo" según Arca, narrativa, 9 octubre 2014) y lo femenino (vestido femenino, también según Arca). La mayoría asocia esta imagen femenina con ser luchadora, con la fuerza y con la pose flamenca. Se suceden los calificativos positivos como "atractiva" (Mariví, narrativa, 3 octubre 2014) y "pedazo de mujer" (Otra Raya más al Tigre, narrativa, 9 octubre 2014) por parte de las informantes heterosexuales, pero también los rechazos de informantes heterosexuales y lesbianas: "no me gusta" dicen Lutecia en su narrativa (2 junio 2015), Blabla (narrativa, 30 septiembre 2014) y Lenademar (narrativa, 22 octubre 2014). Tres informantes la consideran andrógina e incluso Tirita (narrativa, 21 octubre 2014) la califica de "travesti". Como sucedía con la imagen reproducida en la figura 6, la diferencia es valorada positivamente por algunas informantes: NormaRey en su narrativa (9 diciembre 2014) habla de "Diferencia. Orgullo. Masculinidad sensual. Un puto erótico". La lucha es asociada también con la madurez y la serenidad, la fuerza y la sensualidad. Los pechos, como en las figuras hipersexualizadas, vuelven a aparecer como un indicador de femineidad.

Otra de las imágenes de este grupo muestra a dos mujeres bastante similares con gafas de sol, flequillo y pelo rubio, que son calificadas de andróginas, varoniles, indefinidas, ausentes, chicas-chicos Son relacionadas con la modernidad y la belleza. De ellas se destaca sobre todo su mirada, que transmite tristeza, languidez, "homosexualidad" (Otra Raya más al Tigre, narrativa, 9 octubre 2014) o una "relación insana" (Blabla, narrativa, 30 septiembre 2014). Al ser consideradas andróginas, ninguna de las informantes las considera mujeres ni para revistas de hombres ni mujeres objeto mientras que se cuestiona su sexualidad y su personalidad: "modelos, palidez, simetrías, aspectos varoniles, o indefinidos... sin pasión, fríos, distantes, en otra órbita inalcanzable, vacíos, ausentes" (Arca, narrativa, 9 octubre 2014). Marilu en su narrativa (9 marzo 2015) relaciona la imagen con la publicidad de perfumes (sic) que, según ella, muestra a "jóvenes que aparecen, se ven como drogadas o en trance, ésta es una de esas fotos. 
Creo que esos gestos le dan un toque de aire y hacen la atmósfera de la foto más volátil. Las miradas perdidas y las bocas relajadas como los angelitos de las iglesias”. Irónicamente Towanda comenta: "un mundo feliz, todas idénticas" (narrativa, 9 octubre 2014).

La primera imagen de la galería en el orden original en que se envió a las informantes mostraba a una modelo con el pelo corto y caminando con una amplia zancada (ver figura 7). Esta determinación al caminar, junto a su vestimenta (pantalones y corbata), la sitúan como una figura andrógina que provoca rechazo: "no me gusta" (Blabla, narrativa, 30 septiembre 2014). Se la considera como un producto de la moda:

Lo que me transmite esta imagen es la de una mujer creada por los diseñadores de moda en la que sólo sirve para hacerse esta fotografía, no es una mujer real que podría ir por la calle. Se busca una imagen un tanto andrógina en la que parece que al cuello lleva una corbata y sin embargo de calzado lleva unos tacones de escándalo. Se busca solo llamar la atención hacia la fotografía lo que también se aprecia en la pintura tan exagerada que lleva por todo el exterior del ojo. El pelo podría ser el de un hombre y parece además que

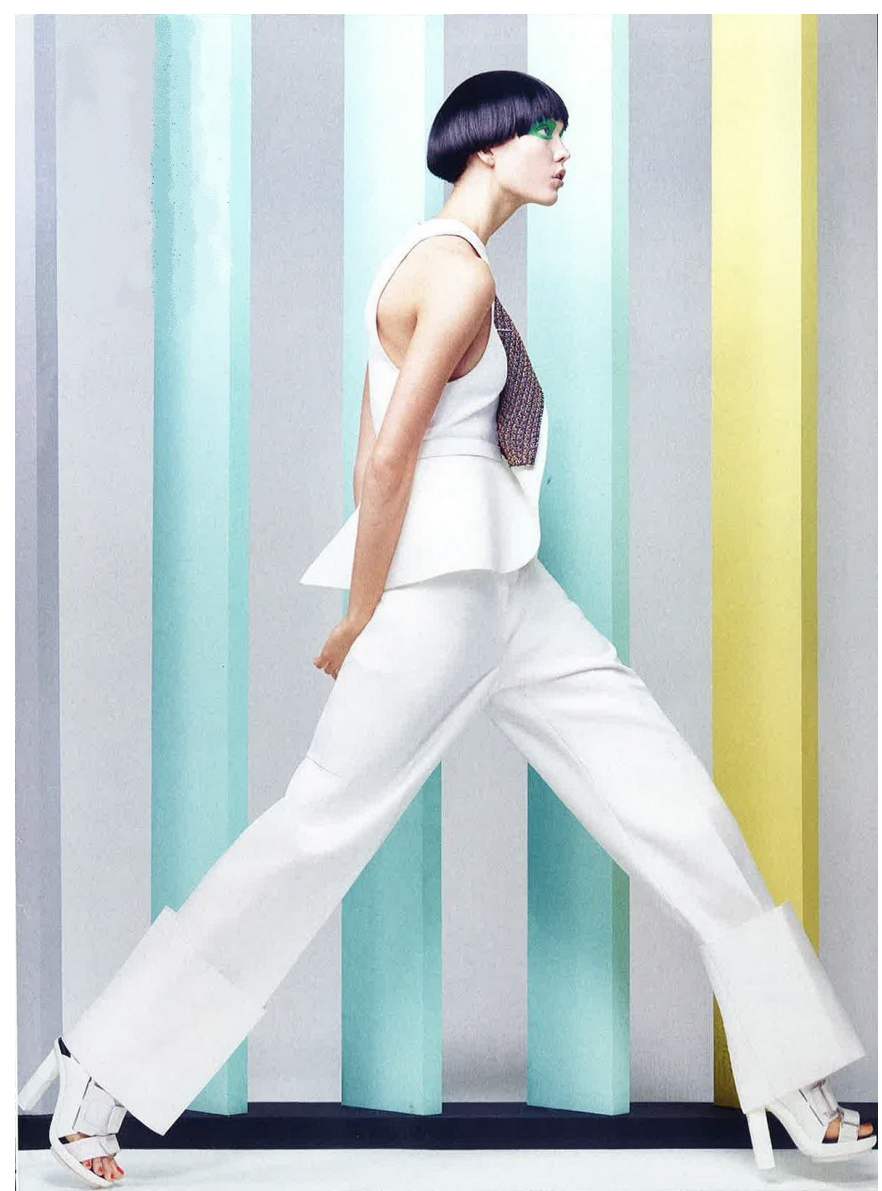

Figura 7. Fuente: Vogue USA, enero 2014 
no lleva pendientes, por otro lado, el cuerpo es demasiado delgado y sin formas, algo que parece gustar a los diseñadores de moda, no sé si porque muchos son homosexuales (eso es lo que se dice pero podría ser un tópico, porque la verdad yo no conozco a ninguno). También posa en una postura un poco extraña, nada femenina y en la que parece que transmite rebeldía (Blabla, narrativa, 30 septiembre 2014).

Estos comentarios ponen de relieve la lejanía de las mujeres de ciertos estilos de moda que obedecen más a criterios estéticos y de mercadotecnia que a las necesidades y cánones de las mujeres reales. También ponen de relevancia cómo los significados de género sirven para hacer juicios de valor y la medida en que perviven los estereotipos. A esta imagen, que no gusta ni a las heterosexuales ni a las lesbianas, se le atribuye indefinición sexual: "Enérgica, no cotidiana (no se ve cada día este tipo), sobremaquillada, artificial, tímida (va con los hombros para adelante), inocente, quizá sin orientación sexual definida" (Tirita, narrativa, 21 octubre 2014).

La galería de imágenes incluía dos fotografías que forman parte de una campaña de los grandes almacenes estadounidenses Barneys, con modelos transgender fotografiados por Bruce Weber.

En una de ellas, el/la modelo, con una larga melena, reposa sobre el tronco de un árbol. Algunas informantes la consideran ambigua (dos heterosexuales: Mes - narrativa, 9 octubre 2014- y Noah Norel, narrativa, 22 octubre 2014) o andrógina (Mjou, lesbiana, narrativa, 9 octubre 2014). El contexto de la imagen adquiere más relevancia en las narrativas que la propia figura humana y la impregna de características relativas a lo natural y bucólico: "natural, triste, está soñando, transmite naturalidad, tranquilidad, serenidad 'amor'" (Olfarnau, narrativa, 21 octubre 2014). Tranqui-

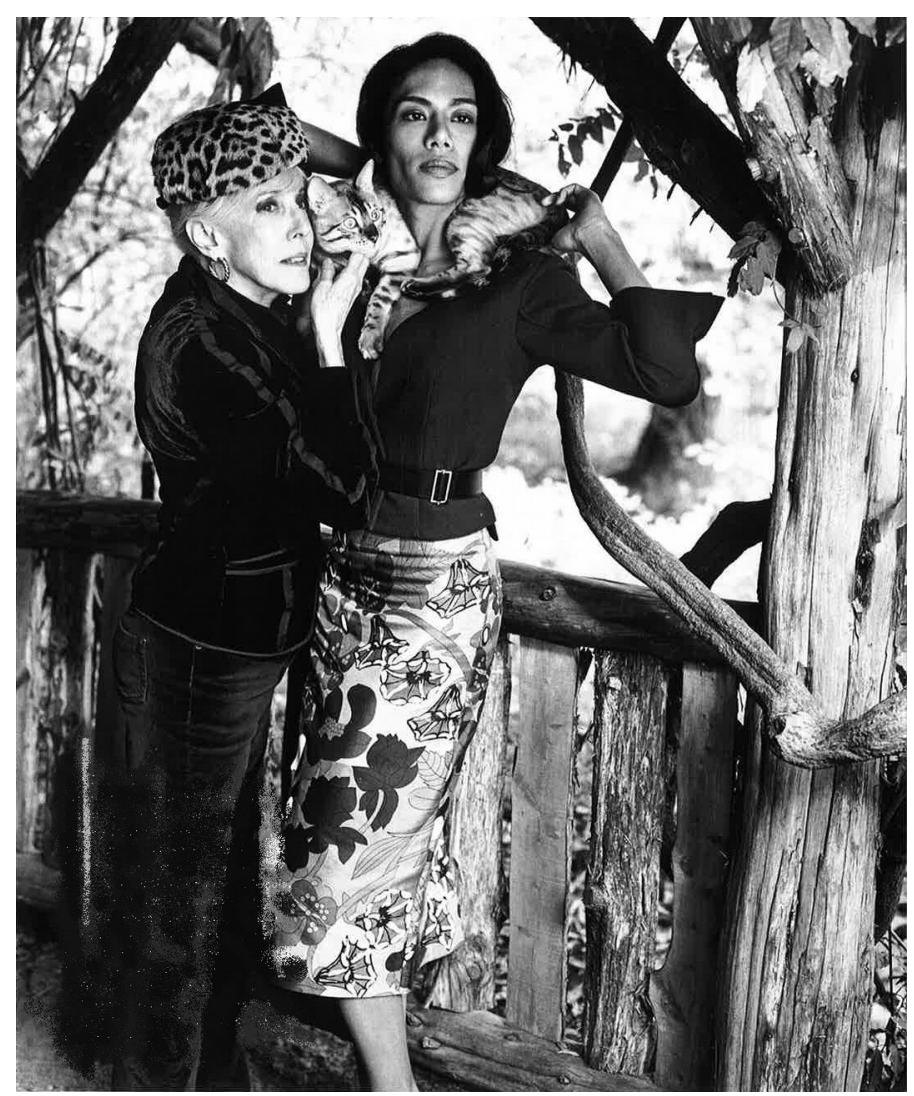

Figura 8. Fuente: Campaña Barneys New York en Vogue USA, marzo 2014 (fotografía de Bruce Weber) 
lidad, serenidad, ensoñación, libertad y naturaleza son conceptos que aparecen con frecuencia asociados a esta imagen: "parece una chica frágil con cara angelical, pero a menudo las apariencias engañan” (Xx, narrativa, 30 septiembre 2014, ).

La segunda imagen de esta campaña incluida en la galería de imágenes (ver figura 8) provoca desconcierto y muchas contradicciones. La imagen se asocia con la edad, lo exótico y lo salvaje; incluso se menciona la "diferencia" pero no se reconoce el componente transgender de la imagen. Por ejemplo, Tirita (bisexual) dice (narrativa, 21 octubre 2014): "me he quedado en blanco. No son pareja, no son madre e hija, son dos estilos muy diferentes (además de edades muy diferentes), el gato no me encaja con la más mayor. La más alta parece travesti pero también podría ser mujer fuertota”. Marilu (heterosexual ${ }^{3}$ ) comenta en su narrativa (9 marzo 2015): "en esta imagen veo una pareja de mujeres muy fuertes, seguras, elegantes, poderosas, dominantes. Podría ser una pareja de socias de alguna empresa, o una pareja de lesbianas. La mujer morena tiene rasgos muy masculinos, me hace pensar que podría ser un travesti muy delicado". Y Lutecia (heterosexual) comenta en su narrativa (2 junio 2015): "la mujer de la derecha parece transexual por sus rasgos faciales, los veo muy varoniles, la de la izquierda no me sugiere nada". Este desconcierto "sexualizado" lleva a Olfarnau a considerar que "transmiten sexo, vicio, jugueteo, representan libertad sexual" (narrativa, 21 octubre 2014). Se califica a la figura a la derecha como transexual (Lutecia, narrativa, 2 junio 2015), "androginia”, hombre, travesti (Tirita, narrativa, 21 octubre 2014; Marilu, narrativa, 9 marzo 2015 ) y a la parecja como lesbianas (Gemma, Marilu), en base a elementos relacionados con el cuerpo, el género y la sexualidad. Pero varias narrativas asociadas a esta imagen también se refieren a la fortaleza que emana de las modelos (Marilu). El juego con el género y la re/presentación es evidente en la narrativa de Ana (21 octubre 2014): "Dos mujeres muy diferentes y muy iguales. De edades diferentes, una rubia y blanca, la otra morena de piel y pelo negro. Una alta, otra baja. Ambas con pose muy femenina, aunque la alta morena sea un chico".

\section{A modo de conclusión: haciendo y deshaciendo cuerpos y géneros}

Uno de los primeros hallazgos de este trabajo es que el posicionamiento de las mujeres ante estas imágenes, su "mirada", suele tomar como referente al otro y no a sí mismas: "A los otros no les gustaría", o "tiene que estar muy segura de sí misma porque no gusta ni a hombres ni a mujeres" son opiniones frecuentes de las informantes. Cuando se critica a las figuras femeninas que aparecen en las imágenes, también ese rechazo está

\footnotetext{
3 En este punto incluimos la referencia a la orientación sexual de las informantes en algunos comentarios por considerar que puede ser una variable relevante para el análisis.
} 
mediado por un tercero, que suelen ser los hombres: "esta chica sólo gusta a los hombres". La relación y la mediación del otro masculino en la mirada femenina es tan fuerte, que incluso algunas narrativas se toman la licencia de dirigirse directamente a ese mediador: "Y tú, burro, a ver si te enteras ya de que el coche no incluye las titis" (Towanda, narrativa, 9 octubre 2014). Los cuerpos femeninos y sus interpretaciones siguen construyéndose en gran medida a partir del otro masculino, de los elementos de belleza que son considerados "preferidos" por los hombres. Esto marca una diferencia respecto a las narrativas masculinas sobre cuerpos masculinos (Enguix, 2012; 2013; 2014) cuya construcción no está mediada por terceros, sino que son los propios informantes quienes adoptan una mirada activa y situada frente a las imágenes que se les muestran.

Las mujeres que se enfrentan a la galería de imágenes, que las miran, las estudian y las comentan, también se posicionan con frecuencia sobre lo que ven, considerando que la representación fotográfica es "adecuada" o "inadecuada" y, con ello, emiten juicios de valor fuertemente influidos por los significados sociales de los géneros. Además, crean una historia alrededor de las imágenes (Valdivia, 1997), tanto cuando la imagen ofrece un contexto que es el punto de partida de su evocación como cuando no ofrece ninguno. En estos casos, infieren a partir de la imagen que se les muestra distintas características (tranquilidad, ensoñación, fuerza, poder, éxito) que se relacionan en general con los cánones normativos de género y belleza. Más que la ropa o el propio cuerpo, son los accesorios y el contexto los que dan lugar a la elaboración de la historia y a la valoración sobre el personaje. Si la mujer representada está en una casa (ver figura 4) es considerada ama de casa, decoradora, escritora, con un marido que la sustenta. El contexto es tan importante para la interpretación y la significación de la imagen que un mismo gesto, como entreabrir la boca, es interpretado como sensual (y rechazado por estar construido para la mirada masculina) o como inocente si la mujer tiene una mirada melancólica y una flor en la boca. Esta "elaboración" de historias sobre la modelo (es una bailarina, es una hippy que está triste, es inocente...) más que (re)significar los cuerpos, con frecuencia los obvia, los sobrevuela, los anula para dibujar un universo de cualidades o carencias que se relacionan tanto con la propia personalidad de la mujer representada como con su belleza, su atractivo para los otros y su éxito personal y social. Así, las informantes se posicionan ante las imágenes con una mirada activa que les sirve para valorarlas o rechazarlas, pero también para inferir significados a partir de los cuerpos representados que trascienden lo corporal y "desbordan” los cuerpos (Enguix, 2013).

Con frecuencia, las imágenes mostradas evocan ideas complejas y contrapuestas, confirmando la complejización de los discursos de género (Enguix, 2015; Gill, 2007). 
Estas ideas "hacen" y "deshacen" el género de las mujeres representadas en la galería fotográfica pero también el de las mujeres que las han analizado, pues mediante este ejercicio de análisis emergen las propias concepciones sobre los géneros. Sus valoraciones no son lineales sino contradictorias; con frecuencia dificultan una identificación nítida de los elementos que "condensan" los significados del género femenino. Aun así, de la clasificación que ha emergido de las narrativas, podemos deducir que los imaginarios femeninos sobre cuerpo-género-sexualidad se construyen hoy en torno a dos procesos muy diferenciados. El primero de ellos es la hipersexualización, entendida como un cuerpo de mujer con atributos sexuales destacados (fundamentalmente pechos, cadera, boca) y/o una pose frente a la cámara interpretada como sensual. El segundo de ellos es la masculinización, la androginia, la ambigüedad, marcada por la ausencia de los atributos presentes en la categoría anterior y también por la presencia de índices masculinos, tanto corporales (como el músculo, un corte de pelo determinado, una cara angulosa, unas venas marcadas) como posturales (una zancada) y actitudinales (firmeza, seguridad). El músculo se convierte en el elemento masculinizante por excelencia. Es aquí donde las narrativas cuestionan la orientación sexual de las modelos, vinculando así con fuerza cuerpo-género y sexualidad y mostrando la pervivencia de los estereotipos (hetero)normativos. En este punto es interesante recordar que la preclasificación de las imágenes operaba fundamentalmente en base al género distinguiendo tres grupos de imágenes: mujeres femeninas, mujeres andróginas y mujeres masculinas (según los cánones al uso). La clasificación surgida de las narrativas mantiene el polo masculino en el que se incluyen las imágenes preclasificadas como "masculinas" y como "andróginas/ambiguas" y distingue dos grupos más: las mujeres erotizadas (o hipersexualizadas) y las mujeres no erotizadas (o tranquilas). Las narrativas solo interrogan la sexualidad de las mujeres representadas en el primer grupo (más masculinas/andróginas), conectando así la interrogación por el género con la interrogación por la sexualidad.

En las narrativas, la normalidad se construye a partir de lo que se considera un término medio que no se posiciona en los extremos porque no contiene rasgos hipersexualizados ni masculinizados. La escasez de maquillaje y las facciones juveniles son consideradas como representativas de la mujer "corriente", "normal" (usamos aquí sus palabras textuales), que transmite dulzura, tranquilidad, sinceridad, honestidad, inocencia y tristeza, con una total ausencia de connotación sexual (p.e. figuras 4 y 7). Este tipo de mujer "natural", "tranquila", construido a partir de rasgos de carácter o en relación a la vestimenta y el contexto, es el más valorado. Aunque en las narrativas surgen cualidades morales, sexuales y de personalidad, la inteligencia o las competencias raramente aparecen asociadas a las imágenes. Las mujeres hipersexualizadas son duramente criticadas por considerarlas modelos "para hombres" mientras que los modelos 
más alternativos provocan rechazo, extrañeza y desconcierto. Con ello, podemos afirmar que en las narrativas se reconoce la existencia de modelos rupturistas de género, pero todavía se basan fundamentalmente en códigos de género heteronormativos, como muestra claramente la interrogación del sexo y de la sexualidad de la modelo respecto al tercer grupo. En consecuencia, este trabajo muestra la continuidad de los significados de género y la persistencia de los estereotipos sin que la edad de las informantes suponga una variable discriminatoria relevante.

La feminidad está fuertemente ligada a los pechos, a los labios y al peinado, que también son los aspectos más sexualizados. Aparecen también como índices femeninos el cuidado de sí, la postura, las uñas pintadas y el maquillaje. La fuerza y la seguridad en una misma se consideran como rasgos masculinos/masculinizantes. Encontramos en las narrativas discursos del feminismo liberal, descritos por Rosalind Gill (2007), indicativos de la existencia de una transición hacia otros modelos posibles de mujeres, aún no asumidos socialmente. Y es interesante destacar que, aunque la diversidad sexual de nuestra muestra de informantes no permite llevar a cabo un análisis detallado de la influencia de la orientación sexual sobre la elaboración de narrativas corporales, podemos apuntar que la orientación sexual de las informantes no parece ser una variable relevante que condiciona sus marcos interpretativos. Un trabajo más detallado en este sentido y con una muestra más amplia nos ayudaría a discernir si $-\mathrm{y}$ de qué modo- los significados de género asociados a lo femenino se relacionan con las distintas orientaciones sexuales y si la orientación sexual es un criterio clasificatorio relevante a estos efectos por dar lugar a marcos de interpretación particulares, como sucede en el caso de los hombres (Enguix, 2012; 2013; 2014).

En las narrativas masculinas, la materialidad física, el cuerpo, es el eje central, confirmando así que la masculinidad es algo relativo al cuerpo más que un estado de la mente (Kimmel, 1996). En las narrativas femeninas, el eje central parece construirse mediante el cuerpo, pero considerado como soporte y no como agente; es un cuerpo que se construye junto con otros "artefactos sociales" como los complementos, la pose y la actitud de las modelos (Enguix, 2012; 2013; 2014; Valdivia, 1997). El cuerpo en sí no parece tener valor, queda subsumido, oculto por la categoría "mujer", producida por la hegemonía patriarcal. La excepción son las mujeres musculadas (grupo 3) e hipersexualizadas (grupo 1), en las que el cuerpo sí emerge como eje central de los discursos de las mujeres participantes en el estudio. Así, se muestra que el género es, para las mujeres, un conglomerado complejo de significados, que oculta y/o desborda el cuerpo, invadiendo el terreno de las sensaciones y las emociones (independencia, tristeza, libertad o determinación) que aparecen con frecuencia en las narrativas. 
En muchas de las narrativas parece posible la existencia del género sin cuerpo, pues las narrativas parten de lo femenino para centrarse más que en sus características corporales (embodied) que no son ni siquiera referenciadas, en lo que las imágenes evocan y transmiten. También parece posible la existencia del género sin la sexualidad, pues ésta sólo aparece en las narrativas como una variable relevante en los márgenes (hipersexualización-virilidad femenina). Esta idea de género sin cuerpo y sin sexualidad, puede vincularse con la reproducción de los cánones normativos, rechazándose por igual el modelo de "mujer objeto" (también considerada como "mujer artificial") y el de "mujer musculada"; también puede relacionarse con la tradicional imagen de la mujer como madre, cuidadora y ser asexual. Las mujeres "normales" de la galería fotográfica, las mujeres "tranquilas", son las más aceptadas, pero suscitan narrativas centradas en cualidades, emociones o sensaciones (hogareña, triste, sensible) que no sólo desbordan el cuerpo, sino que prescinden de él. Sólo tienen género, un género casi intangible, diluido en atributos múltiples. Así, según nuestras narrativas, la agresividad, la independencia y el poder siguen asociadas a lo masculino mientras que la emocionalidad, la pasividad y el cuidado se siguen considerando cualidades femeninas (Francis, 2008, p. 216).

Posiblemente, nos enfrentamos a un vacío de modelos útiles y comprensivos para aproximarnos a las representaciones diversas, a la fluidez de las performances actuales. Retomando los tres elementos de transformación presentes en la contemporaneidad que señalábamos al inicio de este trabajo, podemos afirmar que la combinación de características masculinas y femeninas (dureza junto con sensibilidad) así como la importancia otorgada al contexto y a los complementos parecen indicar que, a la luz de las narrativas analizadas, el género y la re/presentación de sí se entienden como actos performativos más que como señales inequívocas de identidades estables y naturalizadas. Las "agencias" femeninas son negociadas: allí donde afloran significados tradicionales respecto a una imagen -como la figura 6- que para algunas representa "un cuerpo de hombre con cara de mujer" (Alicia en el país de las maravillas, narrativa, 30 septiembre 2014), otras ven "el valor de ellas a perder esa 'feminidad' mal entendida socialmente, renunciar al aspecto femenino obligado" (Marichuli, narrativa, 9 octubre 2014). Las tensiones y contradicciones posfeministas respecto a los significados de la feminidad parecen ser evidenciados en las narrativas.

Hemos encontrado también puntos de ruptura con la heteronormatividad, particularmente en las críticas unánimes respecto al modelo de "mujer para revista de hombres", objetificada y sexualizada. Este modelo de mujer ha pasado, aparentemente, de ser valorado a ser fuertemente criticado precisamente por la falta de agencia que implica. Se valora el cuerpo pero también la seguridad en una misma. Leer en clave "mas- 
culina" tanto la seguridad en una misma como ciertas posturas corporales (firmes) muestra que, a pesar de los puntos de ruptura, las narrativas aún están colonizadas por el binarismo de género y los estereotipos tradicionales. Por ese motivo, y respecto al tercer elemento de transformación que señalábamos (la visibilidad de distintas prácticas sexuales y de referencias simbólicas sobre la sexualidad femenina y su influencia sobre la emergencia de nuevos modelos de belleza) hemos constatado que la mayoría de modelos alternativos presentes en la galería (agender, transgender) han pasado desapercibidos a las miradas no "expertas" de las informantes. Aun así, en los casos en que la "diferencia" era evidente (mujeres musculadas), las narrativas han adoptado posicionamientos ambivalentes que muestran que existe una reafirmación de los valores tradicionales sobre el sistema cuerpo-género-sexualidad y la comprensión de la belleza, pero también que en estos valores se están abriendo brechas de superación del binarismo.

\section{Anexo}

\section{Revistas consultadas}

Catálogo primavera-verano 2014 firma Cotélac (cortesía de la firma)

Catálogo primavera-verano Violeta by Mango (cortesía de la firma)

Catálogo de primavera 2015 de Mango

Cosmopolitan España, núm. 281, febrero 2014

Esquire, num. 73, abril 2014

Glamour, núm. 136, febrero 2014

Harper's Bazaar España, núm. 44. febrero 2014

Icon, núm 1, noviembre 2013

Icon, núm 4, marzo 2014-03-27

In Style núm. 114, febrero 2014

Loewe: fall winter collection 2007-2008

Número Homme, num 27, primavera-verano 2014

Qué leer, núm. 196, marzo 2014

S Moda, El País, núm. 114, 24 noviembre 2013S Moda, núm. 129. 8 marzo 2014

S Moda, El País, núm 126, 15 febrero 2014

Telva, núm 898, febrero 2014

Telva Belleza (suplemento especial de la anterior)

Vanidad, núm. 202, febrero 2014

Vogue USA, enero 2014

Vogue España, núm. 311, febrero 2014

Vogue USA, marzo 2014 
Woman, núm. 257, febrero 2014

\section{Referencias}

Alcoff, Linda (2002). Feminismo Cultural vs. Post-estructuralismo: la crisis de identidad de la teoría feminista. Debats, 76, 1-26.

Armstrong, Elizabeth A. \& Weinberg, Martin S. (2006). Identity and competence: The use of culture in the interpretation of sexual images. Sociological Perspectives, 49(3), 411-432. https://doi.org/10.1525/sop.2006.49.3.411

Attwood, Feona (Ed.) (2009). Mainstreaming Sex. London: I.B. Tauris and Co.

Bianciotti, Maria Celeste (2011). Cuerpo y género: apuntes para pensar prácticas eróticas de mujeres jóvenes. Aportes de Judith Butler y Pierre Bourdieu. Relaces, Revista Latinoamericana de Estudios sobre Cuerpos, Emociones y Sociedad, 6, 25-38.

Bordo, Susan (2001). El Feminismo, la Cultura Occidental y el Cuerpo. Revista de Estudios de Género. La ventana, 2(14), 7-81.

Bourdieu, Pierre (1997). Razones prácticas. Sobre la teoría de la acción. Barcelona: Anagrama.

Butler, Judith (1990). Gender trouble. New York: Routledge.

Butler, Judith (1993). Bodies that matter. On the discursive limits of "sex". New York: Routledge.

Butler, Judith (2004). Undoing Gender. New York: Routledge.

Callen, Anthea (1998). Ideal Masculinities. An Anatomy of Power. En Nicholas Mirzoeff (Ed.) The Visual Culture Reader, (pp. 603-616). London: Routledge.

Collier, Malcolm (2001). Approaches to Analysis in Visual Anthropology. En Theo Van Leeuwen \& Carey Jewitt (Eds.), Handbook of Visual Analysis (pp. 35-65). London: Sage.

Czarniawska, Barbara (2005). Doing Gender unto the Other: Fiction as a mode of Studying Gender Discrimination in Oorganizations. Gender, Work and Organization, 10(3), 234-253. https://doi.org/10.1111/j.1468-0432.2006.00306.x

Enguix, Begonya (1996). Poder y Deseo. La Homosexualidad Masculina en Valencia. Valencia: Alfons el Magnànim.

Enguix, Begonya (2010). Fronteras, cuerpos e identidades gays. Quaderns de l'ICA, 26, 83-106.

Enguix, Begonya (2012). Cultivando cuerpos, modelando masculinidades. Revista de Dialectología y Tradiciones Populares, 67(1), 147-180. https://doi.org/10.3989/rdtp.2012.06

Enguix, Begonya (2013). Cuerpos Desbordados. La Construcción Corporal de la Masculinidad. Argos, 30(59), 61-86. https://doi.org/10.3989/rdtp.2012.06

Enguix, Begonya (2014). Male Bodies and the Black Male Gaze: Is there a Cultural Interpretation of Masculinities? En Josep Martí (Ed.), African Realities: Body, Culture and Social Tensions (pp. 111-146). Newcastle upon Tyne: Cambridge Scholars Publishing. 
Enguix, Begonya \& Nuñez, Francesc (2015). Género, Sexualidad Posfeminismo en 50 Sombras de Grey. AIBR, Revista de Antropología Iberoamericana, 10(1), 49-74. https://doi.org/10.11156/aibr.100104

Featherstone, Mike (1982). The Body in Consumer Culture. Theory, Culture and Society, 1, 18-33. https://doi.org/10.1177/026327648200100203

Foucault, Michel (1984). Historia de la Sexualidad (I). La Voluntad de Saber. Madrid: Siglo XXI.

Foucault, Michel (1991). Tecnologías del Yo. Barcelona: Paidós.

Francis, Becky (2008). Engendering debate: how to formulate a political account of the divide between genetic bodies and discursive gender? Fournal of Gender Studies, 17(3), 211- 223. https://doi.org/10.1080/09589230802204241

Galak, Eduardo (2011). Con Bourdieu y contra Bourdieu. Reflexiones sobre la relación habitus y cuerpo. En Victoria D’Hers y Eduardo Galak (Comp.), Estudios Sociales sobre el Cuerpo: Prácticas, Saberes, Discursos en Perspectiva (pp 38-56). Buenos Aires: Estudios Sociológicos Editora.

Giddens, Anthony (1994). Modernidad e identidad del yo. El yo y la sociedad en la época contemporánea. Barcelona: Península.

Gill, Rosalind (2003). From sexual objectification to sexual subjectification: the resexualisation of women's bodies in the media. Feminist Media Studies, 3(1), 100-106. https://doi.org/10.1080/1468077032000080158

Gill, Rosalind (2007). Postfeminist media culture: elements of a sensibility. European Journal of Cultural Studies, 10(2), 147-166. https://doi.org/10.1177/1367549407075898

Gill, Rosalind (2008). Empowerment/Sexism: Figuring Female Sexual Agency in Contemporary Advertising. Feminism \& Psychology, 18, 35-60. https://doi.org/10.1177/0959353507084950

Goffman, Erving (1979). Gender Advertisements. Nueva York: Harper and Row.

Goffman, Erving (1987). La Presentación de la Persona en la Vida cotidiana. Buenos Aires: Amorrortu-Murguía.

Grosz, Elizabeth (1994). Volatile Bodies. Bloomington: Indiana University Press.

Hall, Stuart (1980). Encoding/decoding. En Stuart Hall, Doothy Hobson, Andrew Lowe \& Paul Willis (Eds.), Culture, Media, Language (pp. 128-138). London: Hutchinson.

hooks, bell (1996). Reel to Real. Race, Sex and Class at the Movies. Londres: Routledge. Howson, Alexandra (2005). Embodying Gender. Londres: Sage.

Jeffreys, Sheila (2005). Beauty and Misogyny. Harmful cultural practices in the west. London and New York: Routledge.

Johnson, Kim K.P. \& Lennon, Sharron J. (Eds.) (1999). Appearance and Power. New York: Berg.

Kimmel, Michael (1996). Manhood in America: A Cultural History. New York: Free Press.

List Reyes, Mauricio (2005). Hombres: cuerpo, género y sexualidad. Cuicuilco, 33, 173202. 
McRobbie, Angela (2004). Postfeminism and popular culture. Feminist Media Studies, 4(3), 255- 264. http://dx.doi.org/10.1080/1468077042000309937

Nixon, Sean (2003). Advertising Cultures. London: Sage.

O’Barr, William M. (2008). Representations of Masculinity and Femininity in Advertisements. Advertising and Society Review, 7(2), 1-31. https://doi.org/10.1353/asr.2006.0028

Paasonen, Susanna; Nikunen, Kaarina y Saarenmaa, Laura (Eds.) (2007). Pornification. Sex and Sexuality. Media Culture. New York: Berg.

Radner, Hilary (1999). Queering the Girl. En Hilary Radner \& Moya Luckett (Eds.) Swinging Single. Representing Sexuality in the 1960s (pp. 1-38). Minneapolis: University of Minnesota Press.

Ragusa, Angela T. (2003). Social Change in the Media: Gay, Lesbian, Bi, Trans and Queer (GLBTQ) Representation and Visibility in The New York Times. A Critical, Qualitative Social-Historical Content Analysis of The New York Times. (tesis doctoral) http://scholar.lib.vt.edu/theses/available/etd-01232003180107/unrestricted/Angelaragusadissert.pdf

Riley, Sarah C.E. \& Christina, Scharff (2013). Feminism versus femininity? Exploring feminist dilemmas through cooperative inquiry research. Feminism \& Psychology, 23, 207-221. https://doi.org/10.1177/0959353512454615

Rohlinger, Deana A. (2002). Eroticizing Men: Cultural Influences on Advertising and Male Objectification. Sex Roles, 3(4), 61-74. https://doi.org/10.1023/A:1016575909173

Rubin, Gayle (1975/1996). El tráfico de mujeres: Notas sobre la "economía política” del sexo. En Marta Lamas (Comp.), El género: la construcción cultural de la diferencia sexual (pp. 35-96). México DF: PUEG.

Rubin, Gayle (1984/1989). Reflexionando sobre el sexo: notas para una teoría radical de la sexualidad. En Carole S. Vance (Comp.), Placer y peligro. Explorando la sexualidad femenina (pp. 113-190). Madrid: Revolución.

Saucier, Jason \& Caron, Sandra L. (2008). An Investigation of Content and Media Images in Gay men's magazines. Journal of Homosexuality, 55 (3), 504-523. https://doi.org/10.1080/00918360802345297

Schroeder, Jonathan E. \& Zwick, Detlev (2004). Mirrors of Masculinity: Representation and Identity in Advertising Images. Consumption, Markets \& Culture, 7(1), 2152. https://doi.org/0.1080/1025386042000212383

Shilling, Chris (1993). The Body and Social Theory. London: Sage.

Shilling, Chris (2005). The Body in Culture, Technology and Society. London: Sage.

Turner, Bryan S. (1984). Body and Society. Oxford: Basil Blackwell.

Valdivia, Angharad N. (1997). The Secret of My Desire: Gender, Class, and Sexuality in Lingerie Catalogs. En Katherine Toland Frith (Ed.) Undressing the Ad: Reading Culture in Advertising (pp. 225-250). Berna: Peter Lang.

Van Zoonen, Liesbet (1994). Feminist Media Studies. London: Sage. 


\section{(c) (1)}

Este texto está protegido por una licencia Creative Commons 4.0.

Usted es libre para Compartir — copiar y redistribuir el material en cualquier medio o formato- y Adaptar el documento - remezclar, transformar y crear a partir del material - para cualquier propósito, incluso comercialmente, siempre que cumpla la condición de:

Atribución: Usted debe reconocer el crédito de una obra de manera adecuada, proporcionar un enlace a la licencia, e indicar si se han realizado cambios. Puede hacerlo en cualquier forma razonable, pero no de forma tal que sugiera que tiene el apoyo del licenciante o lo recibe por el uso que hace.

$\underline{\text { Resumen de licencia - Texto completo de la licencia }}$ 